\title{
A lithosphere-scale structural model of the Barents Sea and Kara Sea region
}

\author{
P. Klitzke ${ }^{1,2}$, J. I. Faleide ${ }^{3}$, M. Scheck-Wenderoth ${ }^{1,2}$, and J. Sippel ${ }^{1}$ \\ ${ }^{1}$ Helmholtz Centre Potsdam, GFZ German Research Centre for Geosciences, Potsdam, Germany \\ ${ }^{2}$ RWTH Aachen University, Dept. of Geology, Geochemistry of Petroleum and Coal, Aachen, Germany \\ ${ }^{3}$ Department of Geosciences, University of Oslo, Oslo, Norway \\ Correspondence to: P. Klitzke (klitzke@gfz-potsdam.de)
}

Received: 27 May 2014 - Published in Solid Earth Discuss.: 10 July 2014

Revised: 2 December 2014 - Accepted: 14 December 2014 - Published: 12 February 2015

\begin{abstract}
We introduce a regional 3-D structural model of the Barents Sea and Kara Sea region which is the first to combine information on the sediments and the crystalline crust as well as the configuration of the lithospheric mantle. Therefore, we have integrated all available geological and geophysical data, including interpreted seismic refraction and reflection data, seismological data, geological maps and previously published 3-D models into one consistent model. This model resolves four major megasequence boundaries (earliest Eocene, mid-Cretaceous, mid-Jurassic and mid-Permian) the top crystalline crust, the Moho and a newly calculated lithosphere-asthenosphere boundary (LAB). The thickness distributions of the corresponding main megasequences delineate five major subdomains (the northern Kara Sea, the southern Kara Sea, the eastern Barents Sea, the western Barents Sea and the oceanic domain comprising the NorwegianGreenland Sea and the Eurasia Basin). Relating the subsidence histories of these subdomains to the structure of the deeper crust and lithosphere sheds new light on possible causative basin forming mechanisms that we discuss.

The depth configuration of the newly calculated LAB and the seismic velocity configuration of the upper mantle correlate with the younger history of this region. The western Barents Sea is underlain by a thinned lithosphere $(80 \mathrm{~km})$ resulting from multiple Phanerozoic rifting phases and/or the opening of the NE Atlantic from Paleocene/Eocene times on. Notably, the northwestern Barents Sea and Svalbard are underlain by thinnest continental lithosphere $(60 \mathrm{~km})$ and a low-velocity/hot upper mantle that correlates spatially with a region where late Cenozoic uplift was strongest. As opposed to this, the eastern Barents Sea is underlain by a thicker litho-
\end{abstract}

sphere $(\sim 110-150 \mathrm{~km})$ and a high-velocity/density anomaly in the lithospheric mantle. This anomaly, in turn, correlates with an area where only little late Cenozoic uplift/erosion was observed.

\section{Introduction}

Though of increasing economic relevance, intra-continental basins are poorly understood in terms of processes controlling their evolution (Allen and Allen, 2013; Cloetingh and Burov, 2011; Gac et al., 2013; Heine et al., 2008). To comprehend the influence of possible causative subsidence mechanisms as mentioned by Heine et al. (2008), the presentday lithosphere-scale geological configuration needs to be assessed. Essential progress can be made by integrated 3-D models. Such models can be used as a base for structural analysis but also to constrain the distribution of physical properties (i.e. density and temperature) and their impact on different processes.

The Barents Sea and Kara Sea region is situated in such an intra-continental setting bordered by the ancient East European Craton in the southeast and two young passive margins in the north and in the west (Fig. 1). This region has experienced a manifold tectonic history involving multiple orogenies, episodes of intense subsidence and young continental break-up. Thereby, the orogenies are assumed to locally have set the structural grain of the deeper lithosphere which entailed different types of basin formation mechanisms. Due to the assumed potential for hydrocarbon resources, the geodynamically complex setting of the Barents Sea and Kara Sea 
region has been in the focus of both academic and industrydriven studies for decades which have contributed to the accumulation of a large geological and geophysical database.

Recent studies made significant progress in integrating data for larger parts of the Barents Sea. These studies focused either on the sedimentary succession (Clark et al., 2013a, b; Henriksen et al., 2011b), the crystalline crust (Hauser et al., 2011; Marello et al., 2013; Ritzmann et al., 2007) or address only subparts of the Barents Sea and Kara Sea region (Barrère et al., 2009; Breivik et al., 2003, 2005; GlørstadClark, 2011; Piskarev and Shkatov, 2012; Ritzmann and Faleide, 2009). Consequently, there is only limited knowledge about spatial correlations between the thickness configuration of the sedimentary succession, the crystalline crust and the lithospheric mantle for the greater Barents Sea and Kara Sea region.

In the frame of this study, we extend the region of interest beyond the Barents and Kara shelves towards the west- and northwards adjoining young oceanic domains and towards the ancient craton (Baltica) in the southeast. We aim to integrate all publicly available geological and geophysical data (from the Norwegian and Russian parts of the shelf) into a lithosphere-scale regional 3-D model that resolves the firstorder characteristics of the sedimentary fill, the crystalline crust and the lithospheric mantle. Subsequently, we analyse how far characteristics of the 3-D structural model provide new insights into the relation between these different depth levels in different subdomains. In particular, the variations of sedimentary thicknesses (subdivided into megasequences reflecting the main geological episodes) over the entire region are integrated with information on the underlying lithosphere for the first time and discussed in the context of regional geodynamics.

\section{Geological setting}

The tectonic evolution of the Barents Sea and Kara Sea region (Fig. 1) is characterised by several orogenic phases which assembled different lithospheric domains (Gac et al., 2013; Gee et al., 2006; Gudlaugsson et al., 1998; Marello et al., 2013; Otto and Bailey, 1995; Pease and Scott, 2009; Ritzmann and Faleide, 2007, and references therein). It is well known that the composite and heterogeneous basement has experienced locally intense subsidence since Paleozoic times that gave way to the accumulation of up to a $20 \mathrm{~km}$ thick sedimentary succession (Johansen, 1992). The corresponding present-day configuration of the top crystalline crust reveals structural highs and lows of different wavelengths across the Barents and Kara shelves implying that subregions are underlain by different basement domains and structural grains (Figs. 1, 2).

After the assemblage of the East European Craton (Baltica) at ca. 2.0-1.7 Ga (Bogdanova et al., 2008) the first major tectonic event involving plate accretion occurred in the

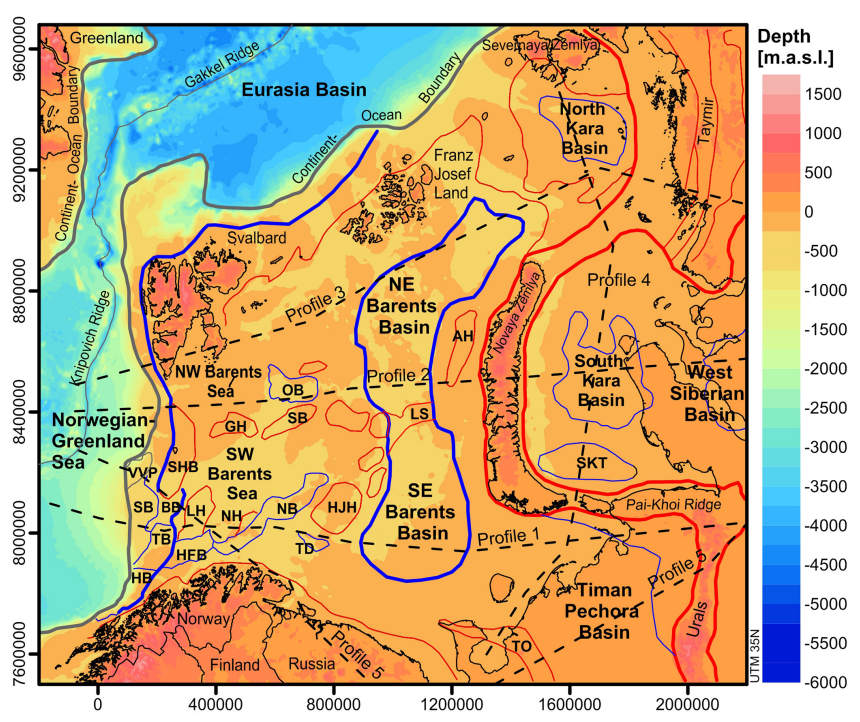

Figure 1. Superimposed bathymetry/topography (IBCAO 3.0; Jakobsson et al., 2012) with outlines of structural highs (red) and lows (blue). The stippled lines mark the position of five representative profiles (see Fig. 6) crossing most prominent geological provinces. $(\mathrm{AH})$ - Admiralty High; (BB) - Bjørnøya Basin; (GH) - Gardarbanken High; (HFB) - Hammerfest Basin; (HB) Harstad Basin; (HJH) - Hjalmar Johansen High; (LH) - Loppa High; (LS) - Ludlov Saddle; (NB) - Nordkapp Basin; (NH) Norsel High; (NSW) - North Siberian Weir; (OB) - Olga Basin; (SB) -Sørvestsnaget Basin; (SKT) - South Kara Trough; (SHB) Stappen High with Bjørnøya Island; (TD) - Tiddlybanken Basin; (TO) - Timan Orogen; (TB) - Troms $\varnothing$ Basin; (VU) - Vize-Ushakov Rise; (VVP) - Vestbakken Volcanic Province.

latest Precambrian in the course of the Timanian Orogeny (Fig. 2; Kostyuchenko et al., 2006; Roberts and Siedlecka, 2002). The Timan Range, a present-day topographic high (Fig. 1) located in the southeast of the study area, gives proof of this collisional event. Orogeny-associated terrane accretion proceeded northeastwards from the Timan Range at least to the Timan-Pechora Basin and is assumed to have continued northwards beneath the eastern Barents Sea as far as to the northern Kara Sea (Gee and Pease, 2004; Lorenz et al., 2007; Pease and Scott, 2009). Earliest sedimentation in these regions is reported as having occurred in latest Precambrian times (Ivanova et al., 2011; Klimenko et al., 2011; Lorenz et al., 2007).

The Caledonian Orogeny, caused by the collision between Laurentia and Baltica to form Laurussia (Late Cambrian to Silurian), affected mainly the area of the western Barents Sea. The crystalline crust beneath the southwestern Barents Sea is supposed to represent the northward continuation of the Caledonian thrusts cropping out in northern Norway (Figs. 1, 2; Breivik et al., 1998, 2005; Marello et al., 2013; Ritzmann and Faleide, 2007). The onshore fold and thrust belts compose a series of NE-SW striking nappes - a strike direction that dominates also the structural configuration of 
the basement beneath the southwestern Barents Sea (Breivik et al., 1998; Faleide et al., 1993; Ritzmann and Faleide, 2007). This trend is disputed in recent studies (Gernigon and Brönner, 2012; Gernigon et al., 2014). However, the oldest sediments found in the depressions of the southwestern Barents Sea result from post-Caledonian rifting in late Carboniferous-Permian times and gave way to the formation of e.g. the Nordkapp Basin and the Ottar Basin (Fig. 2; Gudlaugsson et al., 1998; Ritzmann and Faleide, 2007).

The last major orogenic phase affecting larger parts of the Barents Sea and Kara Sea, the Uralian Orogeny, was initiated by the collision of Laurussia with Siberia and Kazakhstan in Late Devonian to Late Permian times (Fig. 2; Otto and Bailey, 1995; Puchkov, 2009; Steer et al., 1998). Evidence of this compressional deformation are the Ural Mountains which continue structurally along the Pai-Khoi and Novaya Zemlya fold-and-thrust belts as far as to the Taimyr region in the northeast of the study area (Fig. 1). In Late Triassic to ?Early Jurassic (post-Uralian) times, Novaya Zemlya experienced final westwards upthrusting. The westward curved shape of the Novaya Zemlya fold-and-thrust belt structurally delimits the southern Kara Sea (Fig. 1) whereby the curvature is assumed to originate from a pre-collisional embayment of Laurussia (Scott and Howard, 2010).

Another tectonic event at the Permian-Triassic transition was the magmatic activity associated with the eruption of the Siberian Traps. Traces of this event are found directly eastwards of the southern Kara Sea in the West Siberian Basin as widespread flood basalts and long-lived subsidence from Middle Jurassic to Cenozoic times (Fig. 2; Nikishin et al., 2002; Reichow et al., 2005; Saunders et al., 2005; Vyssotski et al., 2006). Time-wise coinciding with these collisional and thermal events, the East Barents Sea basin experienced major subsidence in Permian-Triassic times (Figs. 1, 2). Several published studies discuss the nature of the observed rapid subsidence in the East Barents Sea basin since there are no major extensional faults and thus a classical rift scenario is unlikely (Aplonov et al., 1996; Gac et al., 2012, 2013; Ivanova et al., 2011; Johansen, 1992; O'Leary et al., 2004; Petrov et al., 2008; Semprich et al., 2010). Oldest sediments of the South Kara Sea basin are assumed to have accumulated in response to rifting in the Late Permian to Middle Triassic followed by a post-rift thermal subsidence phase lasting until Cenozoic times (Nikishin et al., 2011).

In Middle Jurassic to Early Cretaceous times intense rifting occurred in the southwestern Barents Sea (Fig. 2; Faleide et al., 1993, 2008). Thereby, the location of maximum subsidence shifted westwards with respect to the older (Carboniferous and Late Permian-Triassic) rift basins and resulted in the development of the deep Troms $\varnothing$ Basin, the Sørvestsnaget Basin and the Bjørnøya Basin (Fig. 1). A renewed westward shift in the locus of rifting took place in Late Cretaceous to Paleocene times and resulted in the deposition of thick sedimentary sequences in the Sørvestsnaget Basin and the Vestbakken Volcanic Province along the western Barents Sea that

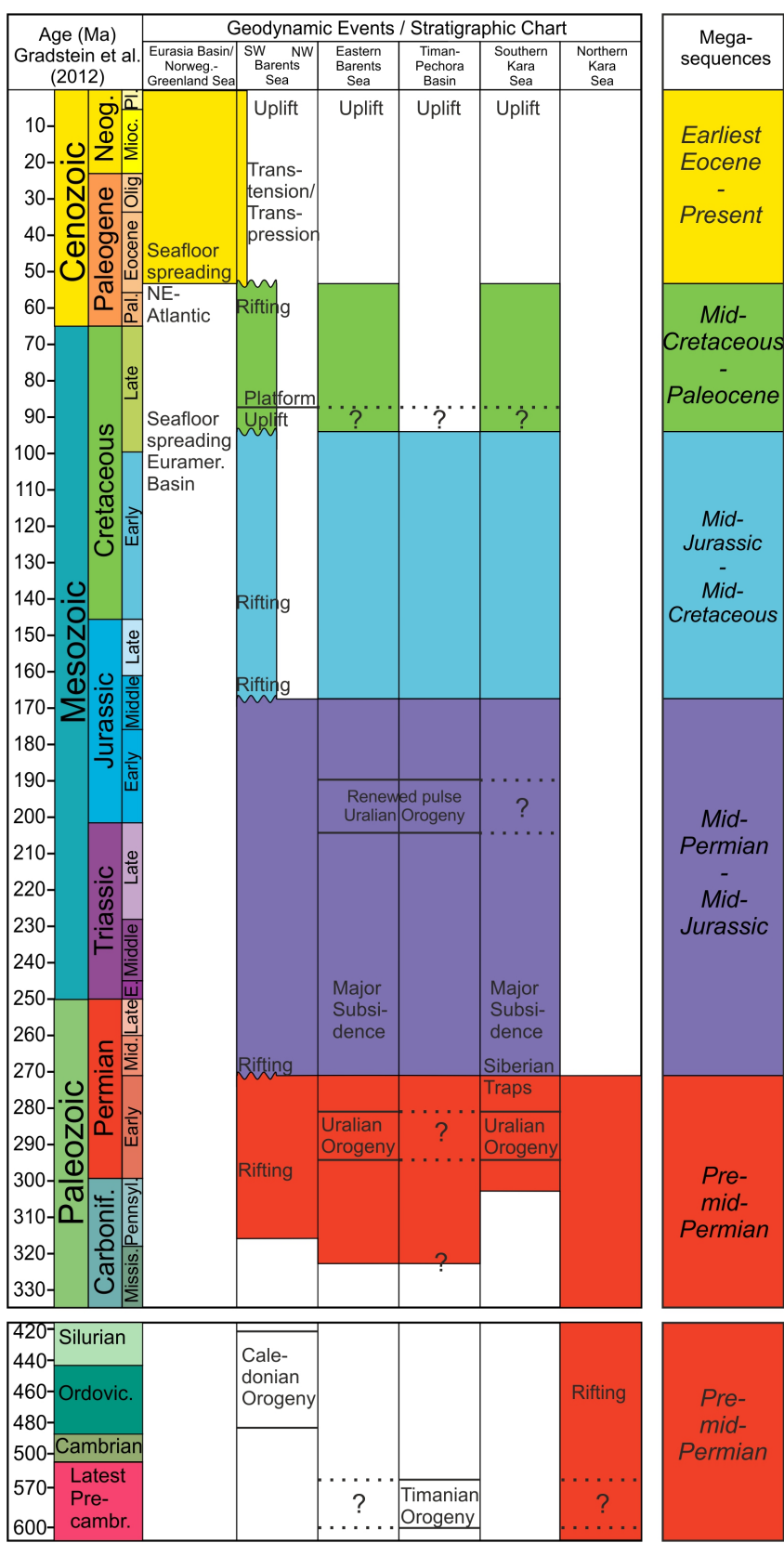

Figure 2. Stratigraphic megasequences resolved in the 3-D structural model in relation to regional tectonic events.

formed a sheared margin during this time interval (Faleide et al., 1993, 2008).

Continental break-up of the Norwegian-Greenland Sea and the Eurasia Basin started in late Paleocene to earliest Eocene times (Figs. 1, 2; Faleide et al., 2008). Thereby, the Norwegian-Greenland Sea opened gradually northwards along a megashear system which constituted a structural link to the Eurasia Basin. The oceanic gateway between the two oceans (Fram Strait) opened finally in mid-Miocene times (Engen et al., 2008). 
In the Pliocene-Pleistocene large areas of the Barents Shelf experienced uplift and glacial erosion (Fig. 2; Dimakis et al., 1998; Dörr et al., 2012; Faleide et al., 1996; Green and Duddy, 2010; Henriksen et al., 2011a; Sobolev, 2012). As a consequence, huge submarine fans (trough-mouth fans; Laberg and Vorren, 1995, 2000) evolved in the adjacent oceanic-crustal domains along the western and northern passive margins (Fig. 1; Knies et al., 2009).

\section{Model construction}

The study area covers beside the Barents and Kara shelves also the oceanic domain adjoining west and northwards, and additionally, the continental mainland of Baltica southeastwards (Fig. 1). To investigate the greater Barents Sea/Kara Sea region on the scale of the entire lithosphere, we have integrated multidisciplinary data such as well information, interpreted seismic refraction and reflection data, geological maps and published 3-D models (Table 1). Since most public data were only available as bitmap information, ArcGIS 10 (Esri) was used to georeference such data sets into a consistent coordinate system (UTM 35N). The georeferenced maps and profiles were imported and compiled with other available data using Petrel 2011.1 (Schlumberger), where the georeferencing was rechecked for accuracy. After having identified the main geological units, the respective scattered data for each surface were interpolated using EarthVision 8.0 (Dynamic Graphics, INC) applying the Minimum Tension Gridding algorithm. Thereby, available vertical fault sets for the Mesozoic and Paleozoic surfaces were considered as vertical interpolation barriers (Fig. 3e, f; Faleide et al., 1993, 2008, 2010; Gudlaugsson et al., 1998). The resulting interpolated surfaces were again visually compared to seismic profiles and potentially corrected when disagreeing with observations or when intersecting with other surfaces.

The continent-ocean boundary (COB) is defined as coinciding with the maximum horizontal Bouguer gravity gradients in the study area and separates the oceanic crust from the continental crust (Fig. 1; Breivik et al., 1999; Minakov et al., 2012a). This is supported by a number of seismic reflection and refraction profiles crossing the continent-ocean transition (Breivik et al., 2003; Czuba et al., 2011; Ljones et al., 2004; Ritzmann et al., 2002, 2004; Voss and Jokat, 2007, 2009). The final 3-D structural model extends $2400 \mathrm{~km}$ in W$\mathrm{E}$ and $2180 \mathrm{~km}$ in N-S direction (Fig. 1) with a horizontal grid spacing of $5 \mathrm{~km}$ and a vertical resolution corresponding to the number of geological units differentiated.

\subsection{Construction of the crustal configuration}

Clark et al. (2013b) and Glørstad-Clark (2011) subdivided the Phanerozoic sedimentary succession in the western Barents Sea using a seismic sequence stratigraphic approach. As a result, the authors were able to determine first-order sequences, so-called megasequences, separated by distinct unconformities. These unconformities either represent erosional surfaces or separate differently deformed sedimentary units. In the frame of this study, we used this sedimentary subdivision in order to differentiate the sedimentary cover of the entire Barents Sea and Kara Sea region even if we knew that the various regions have had a different evolution particularly in the Paleozoic. Therefore, we reviewed and evaluated all available published well and seismic data and traced the megasequence boundaries carefully across the entire study area (Table 1; Faleide et al., 1993; Henriksen et al., 2011b; Ivanova et al., 2011; Johansen, 1992). Even though the data differ significantly in their underlying methodical approach, focus, data resolution and size of the studied area, they comprise depth information on at least one of the mentioned megasequence boundaries (Table 1). Consequently, we were able to model the depth configuration of the earliest Eocene, the mid-Cretaceous, the mid-Jurassic and the mid-Permian megasequence boundaries (Fig. 2). The base of the sedimentary succession is equivalent to the top of the crystalline crust. The bathymetry/topography (BCAO 3.0; Fig. 1; Jakobsson et al., 2012), the four megasequence boundaries and the top crystalline crust were used to calculate the thickness distributions of five megasequences (Fig. 2). Thereby, subtraction of successive depth levels disclosed inconsistencies of the 2-D interpolated surfaces due to intersections. Such intersections were encountered in particular in the southwestern Barents shelf, where large-offset faults are present. To obtain a consistent 3-D structural model, spatial intersections were corrected which entailed a renewed cross-check with the input data. In regions where a megasequence is absent due to non-deposition or erosion, the subtracted base of the megasequence was set equal to the overlying top.

Analogously, the thickness of the crystalline crust has been calculated as the difference between the surfaces of the top crystalline crust and the crust-mantle boundary (Moho) as derived from multidisciplinary data such as refraction seismics, receiver-function analysis and a probabilistic inversion model (Table 1).

\subsection{Modelling of the upper mantle configuration}

The lithospheric thickness is an important parameter required if tectonic processes are studied. The base of the lithosphere, the lithosphere-asthenosphere boundary (LAB), is assumed to represent the rheological transition between the rigid lithosphere where heat transport is mainly conductive to the underlying convection-dominated viscous asthenosphere (Turcotte and Schubert, 2002). Possible factors controlling the viscosity decrease at the $\mathrm{LAB}$ are e.g. temperature, water content, chemical composition and partial melts. Accordingly, the nature of the LAB is discussed extensively in the literature (Eaton et al., 2009; Fischer et al., 2010; Karato, 2012, and references therein). Particularly, partial melting is described to possess the potential to reduce the viscosity 

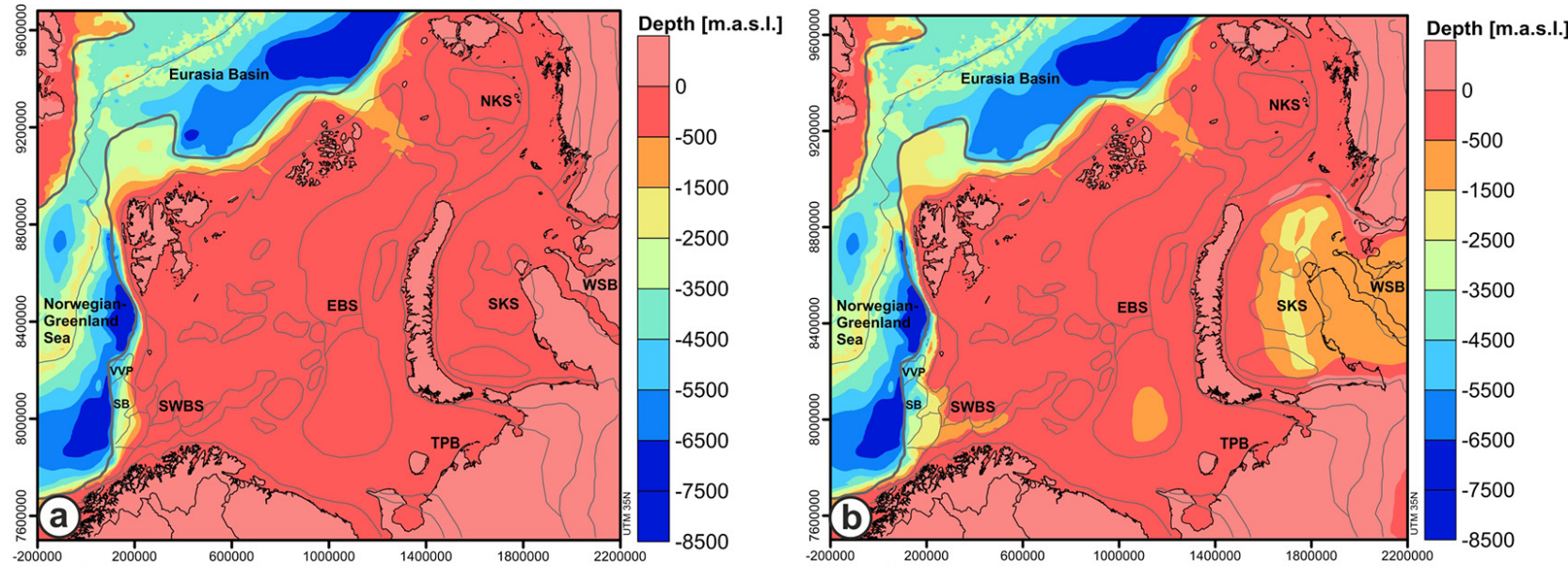

Earliest Eocene
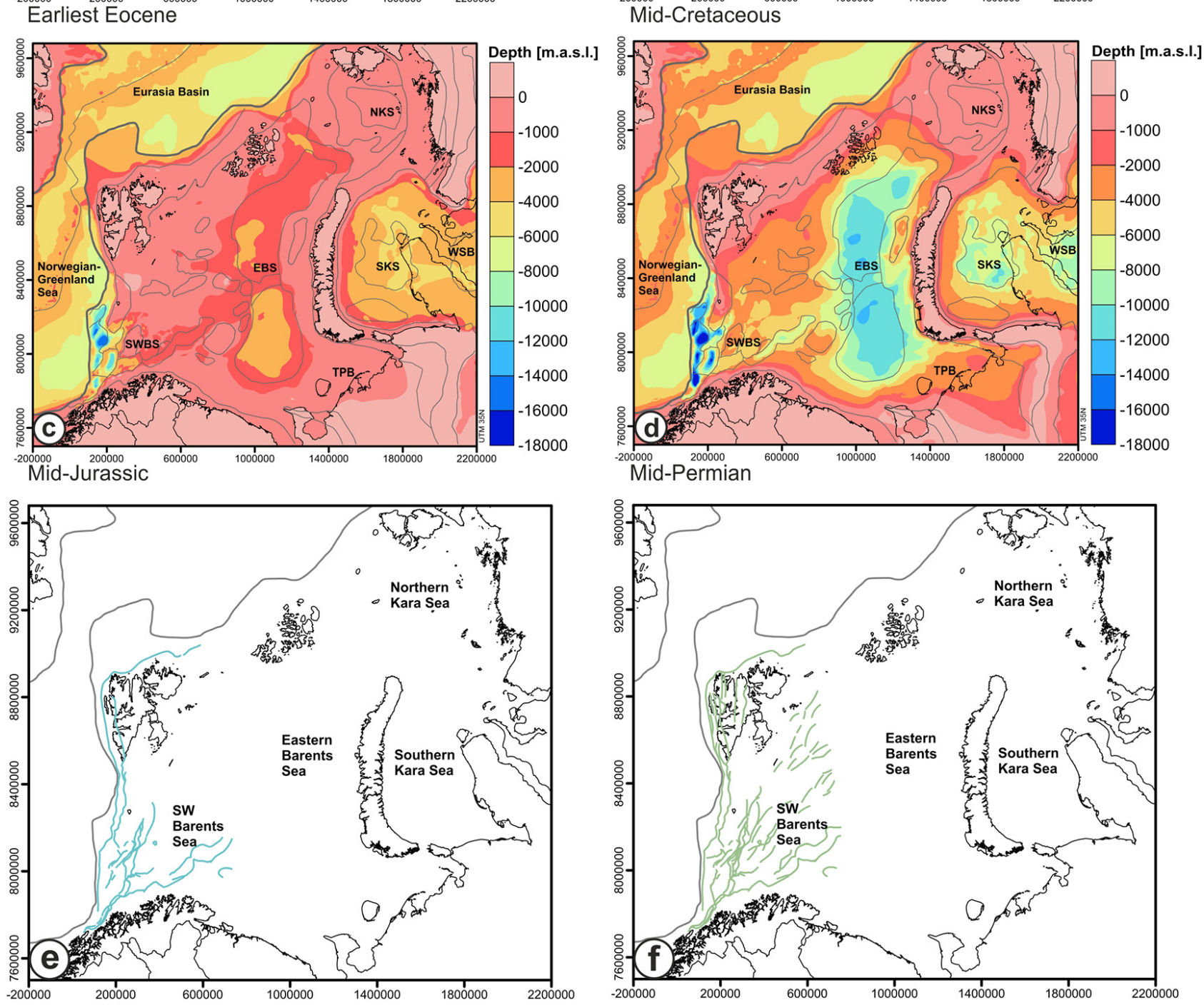

Figure 3. Depth to the four modelled megasequence boundaries: (a) earliest Eocene (b) mid-Cretaceous (c) mid-Jurassic (d) mid-Permian. The grey lines delineate structural features in the study area. The earliest Eocene surface equals the top crystalline crust in the oceanic domain. See Table 1 for the database. (EBS) - eastern Barents Sea; (NKS) - northern Kara Sea; (SB) - Sørvestsnaget Basin; (SKS) - southern Kara Sea; (SWBS) - southwestern Barents Sea; (TPB) - Timan-Pechora Basin; (VVP) - Vestbakken Volcanic Province; (WSB) - West Siberian Basin. Mesozoic (e) and Paleozoic (f) fault-sets (Faleide et al., 1993, 2008, 2010; Gudlaugsson et al., 1998) cover the western Barents Sea and were used as vertical interpolation barriers for the respective megasequence boundaries. 
Table 1. References and coverage for the different horizons of the 3-D structural model.

\begin{tabular}{|c|c|c|}
\hline Horizon & Reference & Covered region \\
\hline Bathymetry & Jakobsson et al. (2012) & Entire study area \\
\hline \multirow[t]{7}{*}{ Earliest Eocene } & Faleide et al. (1996) & Norwegian-Greenland Sea \\
\hline & Fiedler and Faleide (1996) & Norwegian-Greenland Sea \\
\hline & Hjelstuen et al. (1996) & Norwegian-Greenland Sea \\
\hline & Engen et al. (2006) & Eurasia Basin \\
\hline & Engen et al. (2009) & Eurasia Basin \\
\hline & Glebovsky et al. (2006) & Eurasia Basin \\
\hline & Gramberg et al. (2001) & Eurasia Basin \\
\hline \multirow[t]{2}{*}{ Mid-Cretaceous } & Brekhuntsov et al. (2011) & S Kara Sea - W Siberian Basin \\
\hline & Faleide et al. (1993) & SW Barents Sea \\
\hline \multirow[t]{6}{*}{ Mid-Jurassic } & Brekhuntsov et al. (2011) & Southern Kara Sea \\
\hline & Faleide et al. (1993) & SW Barents Sea \\
\hline & Johansen (1992) & Barents Sea \\
\hline & Kontorovich et al. (2010) & Southern Kara Sea \\
\hline & Norwegian Petroleum Directorate & Southern Kara Sea \\
\hline & Piskarev and Shkatov (2012) & Eastern Barents and Kara seas \\
\hline \multirow[t]{7}{*}{ Mid-Permian } & Brekhuntsov et al. (2011) & Southern Kara Sea \\
\hline & Henriksen et al. (2011b) & Barents Sea \\
\hline & Ivanova et al. (2011) & Barents Sea/Kara Sea \\
\hline & Johansen (1992) & Barents Sea \\
\hline & Khutorskoi et al. (2008) & Barents Sea \\
\hline & Nikishin et al. (2011) & Southern Kara Sea \\
\hline & Piskarev and Shkatov (2012) & Eastern Barents and Kara seas \\
\hline \multirow[t]{9}{*}{ Top crystalline crust } & Aplonov et al. (1996) & Eastern Barents and Kara seas \\
\hline & Drachev (2011) & Eastern Barents and Kara seas \\
\hline & Gramberg et al. (2001) & Western Barents Sea \\
\hline & Hauser et al. (2011) & European Arctic \\
\hline & Ivanova et al. (2011) & Barents and Kara seas \\
\hline & Johansen (1992) & Barents Sea \\
\hline & Myklebust 1994) & Barents Sea \\
\hline & Ritzmann et al. (2007) & Barents Sea \\
\hline & Skilbrei (1991) & Barents Sea \\
\hline \multirow[t]{7}{*}{ Moho } & Aplonov et al. (1996) & Eastern Barents and Kara seas \\
\hline & Dahl-Jensen et al. (2003) & NE Greenland \\
\hline & Hauser et al. (2011) & European Arctic \\
\hline & Ivanova et al. (2011) & Barents Sea \\
\hline & Kostyuchenko et al. (2006) & Eastern Barents and Kara seas \\
\hline & Minakov et al. (2012a) & Northern Barents Sea \\
\hline & Ritzmann et al. (2007) & Barents Sea \\
\hline \multirow[t]{4}{*}{ Lithosphere-asthenosphere boundary } & Levshin et al. (2007) & Barents Sea \\
\hline & Kumar et al. (2005) & NE Greenland \\
\hline & Shapiro and Ritzwoller (2002) & Kara Sea \\
\hline & Zhang and Lay (1999) & Oceanic Domain \\
\hline \multirow[t]{3}{*}{ Faults (interpolation barriers) } & Faleide et al. (1993) & SW Barents Sea (Mesozoic) \\
\hline & Faleide et al. $(2008,2010)$ & Western Barents Sea (Paleozoic) \\
\hline & Gudlaugsson et al. (1998) & Western Barents Sea (Paleozoic) \\
\hline
\end{tabular}

significantly even if occurring only in small amounts (Fischer et al., 2010). Shear wave velocities are a well-suited parameter to monitor such viscosity changes and hence, partial melt- ing. To assess the configuration of the lithospheric mantle and to derive information on the depth position of the LAB, we have analysed published shear wave velocity models 
based on surface wave tomography (Levshin et al., 2007; Shapiro and Ritzwoller, 2002).

The regional BARMOD data set (Levshin et al., 2007) is a 3-D shear wave velocity grid with a horizontal resolution of $50 \mathrm{~km}$ and $5 \mathrm{~km}$ in the vertical direction and is based on inverted group-velocity measurements of Love and Rayleigh waves. The 3-D grid comprises information on the 3-D shear wave velocity distribution for large parts of the upper mantle beneath the Barents Sea and northernmost Scandinavia, Novaya Zemlya, Svalbard, Franz Josef Land and the western parts of the southern Kara Sea. Thereby, the path density of Love and Rayleigh waves and the corresponding resolution of the BARMOD model are highest in the western Barents Sea and southeastern Barents Sea and are rather low for the southern Kara Sea. In the oceanic domain, the extent of BARMOD is restricted to the eastern part of the NorwegianGreenland Sea. Vertically, BARMOD reaches down to a maximum depth of $250 \mathrm{~km}$.

As the easternmost continental parts of the study area are not covered by the BARMOD data set, we used the global data set CUB1.0 of Shapiro and Ritzwoller, (2002) as a source of information on the mantle shear wave velocity configuration for this region. This complementary data set has a horizontal resolution of $2^{\circ}$ and a vertical resolution of $4 \mathrm{~km}$ and is also considered in the BARMOD data set.

Both BARMOD and CUB1.0 data sets show mantle shear wave velocities that decrease with increasing depth over a certain depth interval. This zone laterally varies in thickness and depth. Thereby, the deeper the inversion zone occurs the higher are the shear wave velocities. We have determined the depth range of this zone of reduced shear velocities for each $X Y$-position of the 3-D velocity models by calculating the differences in shear wave velocities $\left(\Delta v_{\mathrm{s}}\right)$ between pairs of vertically adjacent grid nodes. Therefore, the shear wave velocity of a grid node located at shallower depth, z1, is subtracted from the velocity at a grid node at larger depth, z2, respectively:

$\Delta v_{\mathrm{s}}=v_{\mathrm{s}, \mathrm{Z} 2}-v_{\mathrm{s}, \mathrm{Z} 1}$.

Accordingly, the 3-D geometry of the mantle zone where a velocity inversion with depth appears, is defined by grid nodes characterised by $\Delta v_{\mathrm{s}}<0$. This reduction corresponds to an inversion of the usual, pressure-controlled trend of increasing velocities with increasing depth $\left(\Delta v_{\mathrm{S}}>0\right)$ as evident above and below this zone of decreasing velocities. $\Delta v_{\mathrm{s}}$ is not uniform over these depth ranges but tends to increase in magnitude from the upper and lower limits of this low-velocity zone (LVZ) towards its centre. In the central parts of the LVZ the vertical velocity gradient is of up to $\Delta v_{\mathrm{s}}=0.02 \mathrm{~km} \mathrm{~s}^{-1}$ per kilometre. We interpreted the depth where the incremental velocity reduction is greatest for an $X Y$-position $\left(\Delta v_{\mathrm{s}}=\right.$ minimum $)$ as the depth at which the geotherm cuts the solidus of mantle rock to induce first significant partial melting. Hence, we mapped the depth of
$\Delta v_{\mathrm{s}}=$ minimum over the spatial extension of BARMOD and CUB1.0 and interpret it as the depth distribution of the LAB.

In the narrow oceanic domain, the BARMOD data set is restricted to the easternmost part of the NorwegianGreenland Sea and the resolution of CUB1.0 is too coarse. Therefore, we were forced to find an alternative approach to derive the depth position of the LAB in the oceanic domain. Interestingly, Zhang and Lay (1999) detected a negative correlation of mid-oceanic spreading rates with recorded surface waves velocities in the Pacific, the Indian and the Atlantic oceans. Slow mid-oceanic spreading rates, as observed in the Atlantic Ocean, are associated with slow mantle upwelling which is thought to lead to a rigidification of the mantle material at greater depths than, for example, in the fastspreading Pacific Ocean. Deep rigidification of mantle material is also observed for the ultraslow-spreading Knipovich Ridge in the Norwegian-Greenland Sea (Dick et al., 2003; Huang and Solomon, 1988; Sauter et al., 2011). Additionally, Zhang and Lay (1999) noticed only a minor lithospheric thickness increase in the Atlantic Ocean with increasing age of the seafloor. Based on their observations the authors set up an empirical equation to calculate the oceanic lithospheric thickness $(L)$ as a function of age $(t)$ for the Atlantic Ocean:

$L=44.6+0.8 \cdot \sqrt{t}$.

The Gakkel Ridge in the Eurasia Basin is, like as the Knipovich Ridge in the Atlantic Ocean, an ultraslowspreading ridge characterised by spreading rates slower than $20 \mathrm{mma}^{-1}$ (Dubinin et al., 2013, and references therein). This justifies the application of the equation of Zhang and Lay (1999) also for the Eurasia Basin. Accordingly, we calculated the oceanic lithosphere thickness using the oceanic age grid of Müller et al. (2008). Where BARMOD extends into the oceanic domain, the depth of the determined LAB is consistent with the LAB modelled according to Zhang and Lay (1999) which again justifies the used approach.

To derive the first depth map of the LAB for the entire study area, we integrated the velocity-derived information (BARMOD, CUB 1.0), oceanic-age related depths as well as information from S-receiver functions for NE Greenland (Kumar et al., 2005).

\section{Results}

\subsection{Structure of the sedimentary infill}

The bathymetry/topography (Fig. 1) represents the uppermost surface of the 3-D structural model and shows typical shallow water depths (average of about $-300 \mathrm{~m}$ ) over the shelf, whereby single archipelagos (Novaya Zemlya, Svalbard, Franz Josef Land) rise to more than $1000 \mathrm{~m}$ a.s.l. The northern and western boundaries of the shelf are characterised by passive margins and a rather steep bathymetric slope defining the transition to the up to $-4000 \mathrm{~m}$ deep 
oceanic domain of the Norwegian-Greenland Sea and the Eurasia Basin.

The earliest Eocene interface (Fig. 3a) represents the shallowest megasequence boundary and equals the bathymetry/topography over wide parts of the continental domain. Only in the southwesternmost Barents Sea do depressions define the transition to the oceanic domain. In the latter, the earliest Eocene surface reaches depths of more than $8000 \mathrm{~m}$ close to the COB. Similar depressions occur also along the northern passive margin in the Eurasia Basin. The earliest Eocene megasequence boundary in the oceanic domain is equivalent to the top of the crystalline crust. According to the depth differences between the bathymetry/topography and the earliest Eocene surface, the thickness distribution of the earliest Eocene present sediments show thickness maxima mostly restricted to the oceanic domain (up to $7500 \mathrm{~m}$ ) whereas significant continental deposits of this age are restricted to the southwesternmost Barents Sea (Fig. 4a).

The mid-Cretaceous megasequence boundary (Fig. 3b) reveals minor depressions in the South Kara Sea basin, in the West Siberian Basin, in the southern part of the East Barents Sea basin and is more markedly in the western Barents Sea (Sørvestsnaget Basin, Vestbakken Volcanic Province). Accordingly, these basins exhibit the largest depth differences between the mid-Cretaceous and the overlying earliest Eocene surface, which is clearly outlined in the calculated thickness distribution of the mid-Cretaceous-Paleocene megasequence (Fig. 4b). Within the southern Kara Sea a mid-Cretaceous-Paleocene depocentre reveals a prominent $\mathrm{N}-\mathrm{S}$ trend. The subbasins of the western Barents Sea, on the other hand, depict different strike directions of thickness maxima ranging from $\mathrm{N}-\mathrm{S}$ in the west (Vestbakken Volcanic Province) to rather ENE-WSW in the east (Hammerfest and Nordkapp basins). Thereby, the wavelength of thickness variations is much shorter in the western Barents Sea than across the remaining study area. These pronounced thickness variations in the western Barents Sea reflect the structural effect of offsets along relatively closely spaced faults (see Mesozoic faults in Fig. 3e).

The mid-Jurassic and the mid-Permian megasequence boundaries (Fig. 3c, d) show similar geometries as the overlying mid-Cretaceous surface with narrow and deep depressions in the western Barents Sea and rather wide depressions in the East Barents Sea basin and the southern Kara Sea. The corresponding sediments of the mid-Jurassic-midCretaceous megasequence attain thicknesses of up to about $11000 \mathrm{~m}$ in the western Barents Sea within a N-S to NESW fan-shaped structure (Fig. 4c, d). Further east in the East Barents Sea basin and the South Kara Sea basin, the midJurassic-mid-Cretaceous unit is characterised by moderate thicknesses $(<3000 \mathrm{~m})$ arranged in a bowl-shaped geometry following the curvature of Novaya Zemlya.

The mid-Permian-mid-Jurassic sediment maxima show a similar distribution pattern to the overlying unit whereby this megasequence is considerably thicker in the basins of the western Barents Sea (absolute thickness of $\sim 15000 \mathrm{~m}$ ), the eastern Barents Sea $(\sim 10500 \mathrm{~m})$ and southern Kara Sea ( 6000 m; Fig. 4 d).

The deepest megasequence overlying the top of the crystalline crust is the pre-mid-Permian megasequence (Fig. 4e) which encompasses numerous small-scale thickness maxima which are mainly related to the topography of the top crystalline crust (Fig. 4f). The western Barents Sea is marked by rather thin pre-mid-Permian sediments which attain up to $\sim 10000 \mathrm{~m}$ in the northern part of the Kara Sea and in the East Barents Sea basin.

The crystalline crust (Figs. $4 \mathrm{f}, 5 \mathrm{~b}$ ) is divided by the COB (continent-ocean boundary) into an oceanic and a continental domain (Fig. 1). In the oceanic domain, the top crystalline crust is modelled as being identical with all megasequence boundaries, since the oceanic crust is younger than the youngest megasequence boundary in the model.

In the continental domain, the top of the crystalline crust reveals significant depth variations (Fig. 4f), especially across the wide shelf areas though the bathymetry is rather uniform (Fig. 1). Given this flatness of the top of the sediments and the consistency of the 3-D structural model, the depth variations of the crystalline crust directly reflect the cumulative thickness variations of the sedimentary megasequences. Accordingly, depressions of the top crystalline crust correlate with domains of larger sediment thickness. The deepest depressions of the top crystalline crust descend down to $14000 \mathrm{~m}$ in the northern and southern Kara Sea and to almost $20000 \mathrm{~m}$ in the East Barents Sea basin and in the western Barents Sea. The distance between basement highs and lows is considerably smaller in the western Barents Sea $(<100 \mathrm{~km})$ compared to the East Barents Sea and Kara Sea basins $(\sim 500 \mathrm{~km})$. The eastern Barents Sea and the Kara Sea are both subdivided into two subbasins separated by structural highs of the crystalline crust (Fig. 4f). Thereby, the prominent structural high separating the northern and southern Kara Sea follows the topographic highs illustrated by the Ural Mountains, the Pai-Khoi and Novaya Zemlya fold-andthrust belts and the Taimyr region (Fig. 1).

\subsection{Crust and mantle structure}

The depth map of the Moho illustrates a stepwise W-E deepening structure (Fig. 5a) with shallowest depths beneath the oceanic domain $(<-15 \mathrm{~km})$, moderate depths beneath the shelf $(-35 \mathrm{~km})$ and largest depths beneath the continental mainland $(<-50 \mathrm{~km})$. Moreover, the continental Moho is essentially shallower $(-24 \mathrm{~km})$ beneath regions situated close to the COB and NW of Svalbard. Beneath the East Barents Sea basin and the northern Kara Sea, the Moho topography is flat at about $-30 \mathrm{~km}$ even below prominent sediment maxima (see Fig. 4d-e). The South Kara Sea basin is underlain by similar Moho depths which are increasing towards the Uralian Orogen in the south, Novaya Zemlya in the west 


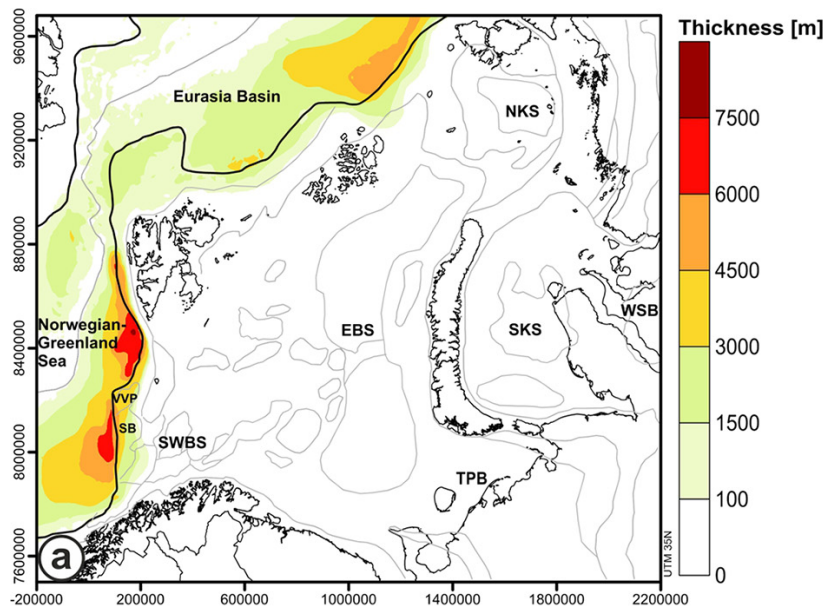

Earliest Eocene - Present sediments

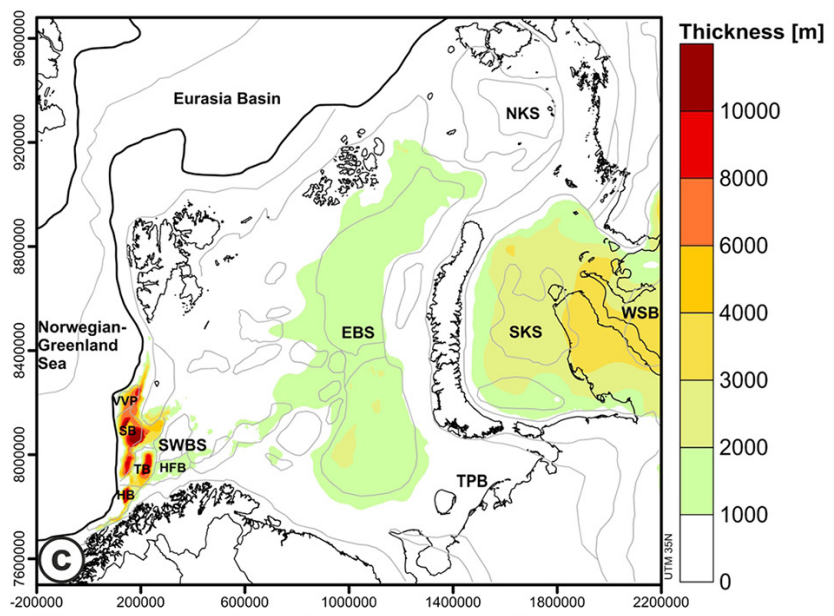

Mid-Jurassic - Mid-Cretaceous sediments

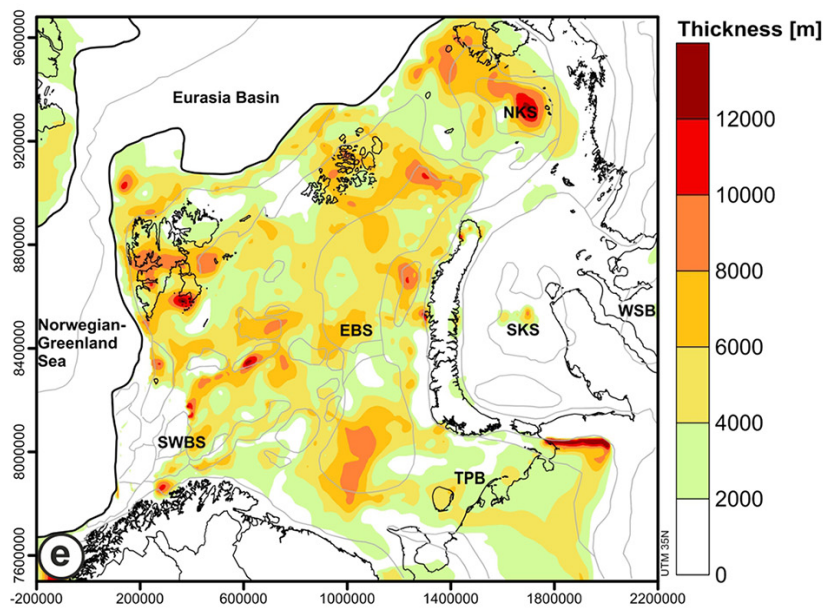

Pre-mid-Permian sediments

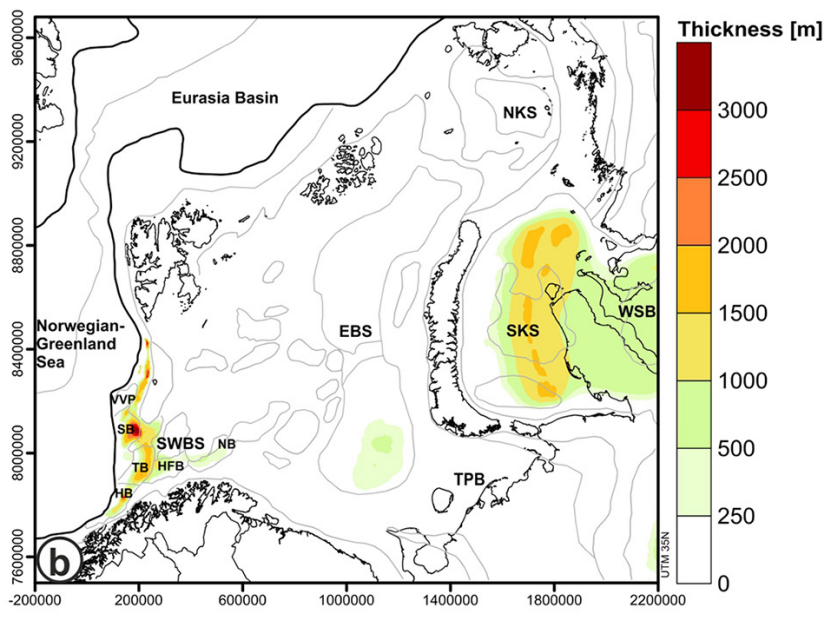

Mid-Cretaceous - Paleocene sediments

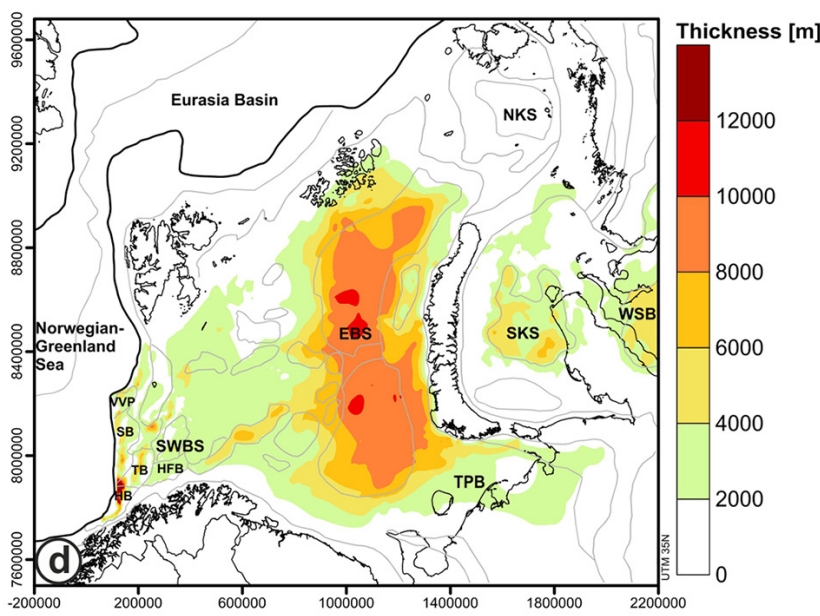

Mid-Permian - Mid-Jurassic sediments

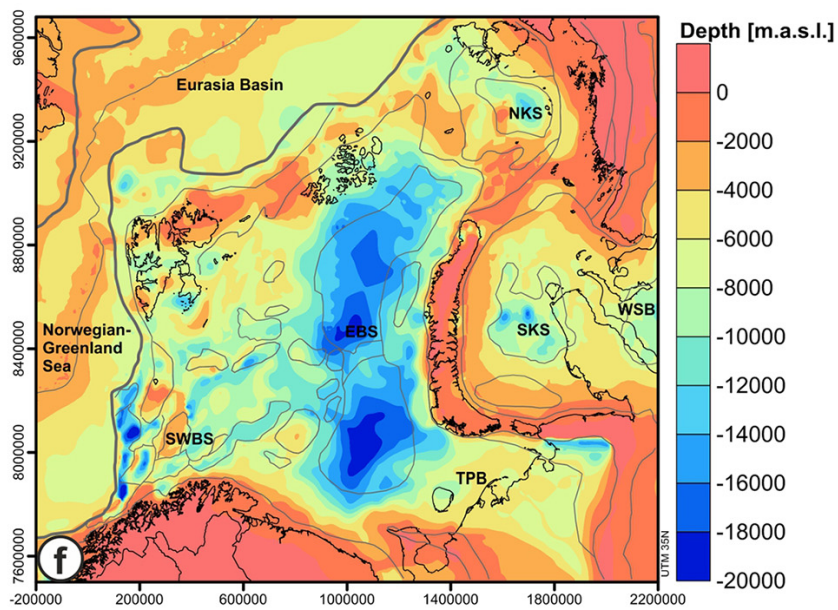

Top Crystalline Basement

Figure 4. Thickness distribution of the megasequences and the depth to the top crystalline crust: (a) Earliest Eocene to Present; (b) MidCretaceous-Paleocene; (c) Mid-Jurassic-Mid-Cretaceous; (d) Mid-Permian-Mid-Jurassic; (e) Pre-mid-Permian; (f) depth to the top crystalline crust. The grey lines delineate structural features in the study area (for legend see Fig. 1b). See Table 1 for database. (EBS) - eastern Barents Sea; (NKS) - northern Kara Sea; (SB) - Sørvestsnaget Basin; (SKS) - southern Kara Sea; (SWBS) - southwestern Barents Sea; (TPB) - Timan-Pechora Basin; (VVP) - Vestbakken Volcanic Province; (WSB) - West Siberian Basin. 

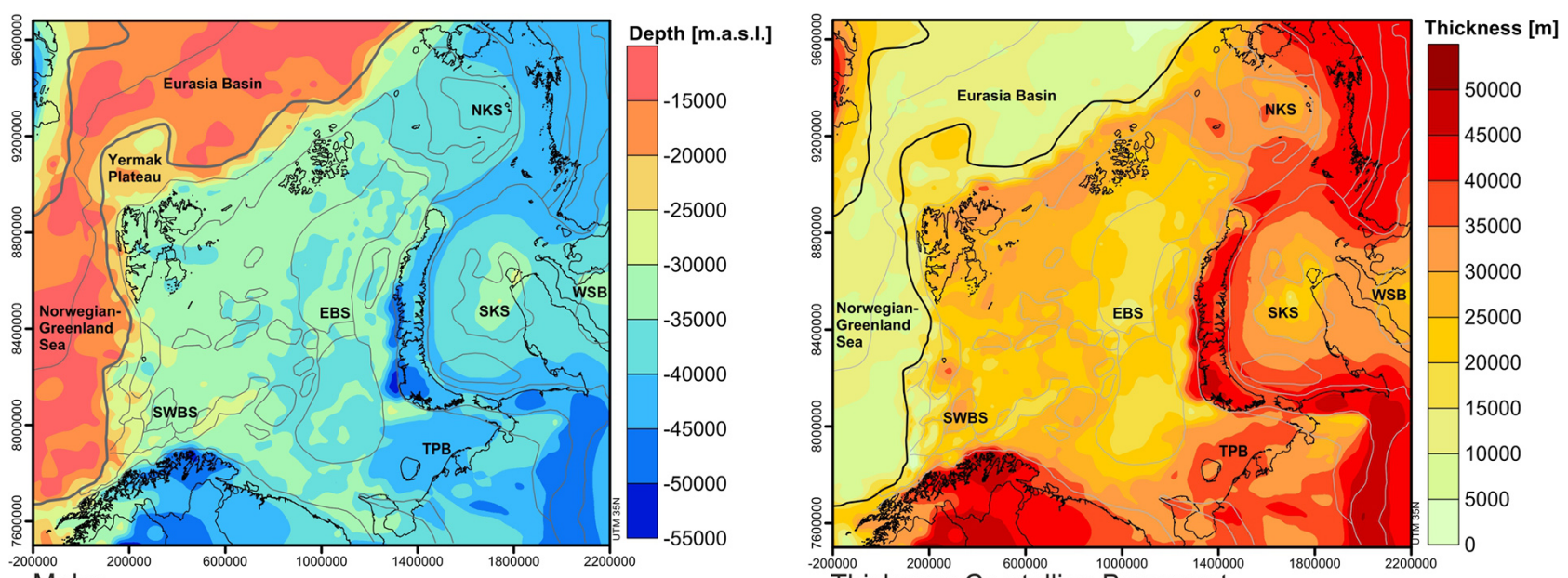

Moho
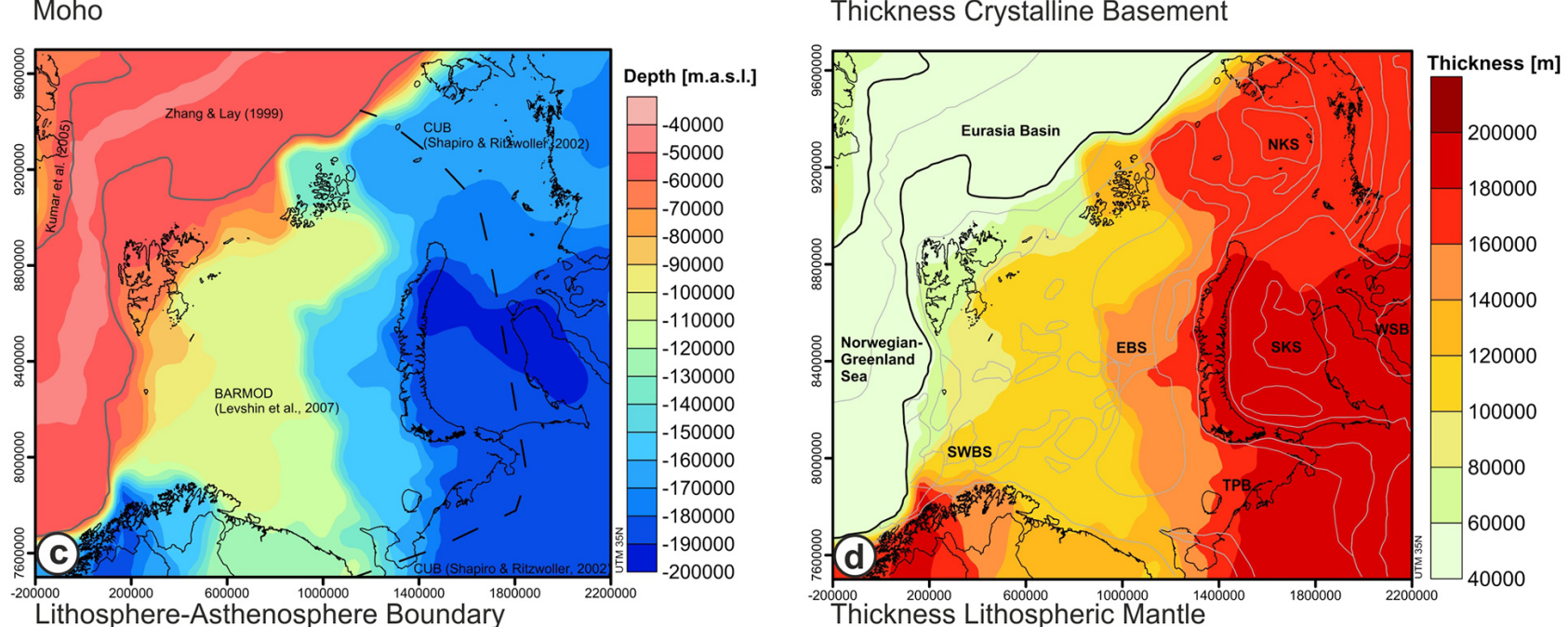

Figure 5. Structure of the deeper crust and the upper mantle: (a) depth to the Moho; (b) thickness of the crystalline crust; (c) depth to the lithosphere-asthenosphere boundary (LAB); (d) thickness of the lithospheric mantle. See Table 1 for the database. (EBS) - eastern Barents Sea; (NKS) - northern Kara Sea; (SKS) - southern Kara Sea; (SWBS) - southwestern Barents Sea; (TPB) - Timan-Pechora Basin; (WSB) - West Siberian Basin.

and Taimyr Peninsula in the north (up to $-50 \mathrm{~km}$ ). Consequently, the crystalline crust is thickest below these thrust and fold belts and towards the Scandinavian shield in the south (Fig. 5b). Below the shelf, the crystalline crust is moderately thick (locally up to $33 \mathrm{~km}$ ) and thinned below regions covered by the thickest sediments (SW Barents Sea basins, East Barents Sea basin, South Kara Sea basin). The oceanic domain is defined by typical crustal thicknesses of $7 \mathrm{~km}$.

As found for the Moho, also the modelled LAB exhibits a comparable step-like W-E deepening with a shallow oceanic LAB $(-50 \mathrm{~km})$, a depth range from -60 to $-155 \mathrm{~km}$ beneath the Barents Sea and the largest depths beneath the Kara Sea and the continental mainland (down to $-200 \mathrm{~km}$; Fig. 5c). Wider domains of a rather flat LAB alternate with narrower transitional domains marked by steep depth gradients. Thereby, the LAB is cutting with depth also higher shear wave velocities. The thickness distribution of the litho- spheric mantle thickness follows the described W-E trend of the LAB relief (Fig. 5d). The thinnest lithospheric mantle is found below the oceanic domain $(40 \mathrm{~km})$, the westernmost Barents Sea and Svalbard (35 km, Fig. 5d). Beneath the shelf, the lithospheric mantle thickens successively from the western Barents Sea $(70 \mathrm{~km})$ eastwards below the East Barents Sea basin $(110 \mathrm{~km})$ and beneath Novaya Zemlya $(135 \mathrm{~km})$. The Kara Sea and the continental domain are underlain by largest lithospheric mantle thicknesses $(175 \mathrm{~km})$. Also, recently published LAB maps show the trend of an shallow LAB beneath Svalbard and a strong deepening towards the Barents Shelf and the continental mainland, though the absolute depths vary significantly between these models (Gung et al., 2003; Koptev and Ershov, 2011; McKenzie and Priestley, 2008; Priestley and McKenzie, 2006).

The integrated structural configuration of the entire lithosphere, including the sedimentary megasequences, the 
crystalline crust, and also the shear wave velocity configuration of the upper mantle, are illustrated on the basis of five regional profiles (Fig. 6a-e) that cross representative domains of the Barents Sea and Kara Sea region (for location see Fig. 1). Moreover, the profiles illustrate the depth distribution of the LVZ with the LAB in its centre. The W-E profiles (Fig. 6a, b, c, e) demonstrate the eastward stepwise deepening of the LAB. Following the mantle shear wave velocities in the same eastward direction, a distinctive increase of velocities is observable from the oceanic to the western Barents Sea and again towards the eastern Barents Sea. Comparing the velocities with the BAREY 1-D reference model shows a $+4 \%$ anomaly in depths of about $90 \mathrm{~km}$ below the eastern Barents Sea (Levshin et al., 2007). The N-S profile (Fig. 6d) illustrates a shallow Moho below the South Kara Sea basin whereby the LAB is rather flat along the profile and shallows only in the northernmost part close to the COB. Also the mantle velocities show no larger anomalies beneath the Kara Sea but are elevated velocities beneath the TimanPechora Basin. This high-velocity anomaly is the continuation from the westward adjoining Eastern Barents Sea.

\section{Discussion}

The 3-D structural model makes it possible to analyse the sedimentary units in terms of depositional centres and associated subsidence patterns. Correlating the shallow sedimentary structure with the deeper crustal and lithospheric configuration including the velocity structure of the upper mantle, we can tentatively interpret spatial correlation of the shallow and deep lithospheric structure to shed light on possible basin formation mechanisms and related geodynamic events.

\subsection{Pre-mid-Permian}

The pre-mid-Permian sedimentary strata constitute the lowermost megasequence which overlays directly the crystalline crust. It has to be noted that the age of basal sediments within the pre-mid-Permian megasequence varies distinctively laterally beneath the Barents Sea and Kara Sea region according to the onset of subsidence as outlined in the geological setting. The differentiation of such deep and old sedimentary rocks from the underlying crystalline crust using seismic imaging techniques alone is challenging. The large depths involve, beside a compaction-induced density increase, also elevated pressure and temperature conditions which enforce diagenesis and enable low-grade metamorphism. As a result, the seismic velocities may be increased and the acoustic impedance between sediments and crystalline crust reduced. This hampers the detectability of sediment-characteristic structures (e.g. stratification) in seismic data which in turn could favour misinterpretation of corresponding reflectors as top crystalline crust. Beside the change in seismic impedance due to contrasting physical properties of the rocks, also high- velocity rocks such as intrusive volcanics (e.g. East Barents Sea basin, Svalbard, Timan-Pechora Basin, West Siberian Basin) aggravate the distinction between sediments and crystalline crust (Artyushkov, 2005; Breivik et al., 2005; Gee et al., 2000; Ivanova et al., 2011; Vyssotski et al., 2006). This may connote locally an underestimation of the pre-midPermian sedimentary thickness and an overestimation of the subsedimentary crustal thickness.

Despite these limitations and uncertainties, the thickness map of the pre-mid-Permian sediments shows reproducible trends as e.g. in the northern Kara Sea where a NW-striking sediment maximum attains a thickness of up to $12500 \mathrm{~m}$ (Fig. 4e). This thickness maximum is oriented almost perpendicular to the prevailing structural orientation of the Barents and Kara shelves where Caledonian and Uralian structural features strike NE-SW and N-S, respectively. Towards the south and the southwest, the pre-mid-Permian sediments are bounded by two structural highs of the crystalline crust (Figs. 4f, 6c, d). The NW-SE orientation of the crustal high separating the eastern Barents Sea and the northern Kara Sea correlates with the interpreted Timanide suture of the northern Kara plate which is assumed to have accreted during the Timanian Orogeny in the latest Precambrian (Lorenz et al., 2007; Pease and Scott, 2009). This may have caused the formation of the NW-striking thickened crust and of the sedimentary basin in the hinterland (Malyshev et al., 2012a). Conversely, the Moho and the LAB are rather flat below the northern Kara Sea and show no characteristic structure (Fig. 5a, c). This indicates that the crustal imprint of a possibly associated thinning event vanished during later basin history or that a subsidence mechanism different from pure extension was responsible for the basin formation.

The western Barents Sea was affected essentially by the Caledonian Orogeny resulting in exhumation and denudation of the hinterland and wide deposition of clastic sediments. The NE-SW to NNE-SSW striking trend of the SW Barents Sea sedimentary basins is assumed to be inherited from the Caledonian Orogeny (Breivik et al., 2005; Gudlaugsson et al., 1998; Ritzmann and Faleide, 2007). Corresponding nappes and thrust sheets are well documented onshore Scandinavia and are supposed to continue beneath the western Barents Sea. However, in recent studies (Gernigon and Brönner, 2012; Gernigon et al., 2014) the striking trend of the nappes and the thrust sheets in the western Barents Sea is disputed based on the analysis of new aeromagnetic data.

The eastern part of the Barents Sea is covered by a thicker section of Devonian and older sediments (up to $6 \mathrm{~km}$ ) and a thinner Carboniferous-early Permian section (up to 2 km; Artyushkov, 2005; Ritzmann and Faleide, 2009) which are integrated in the 3-D model into the pre-mid-Permian megasequence (Fig. 4e). These old sediments are assumed to be the result from Middle Devonian westward subduction (Gac et al., 2012; Nikishin et al., 1996, and references therein) and subsequent back-arc extension and subsidence. 

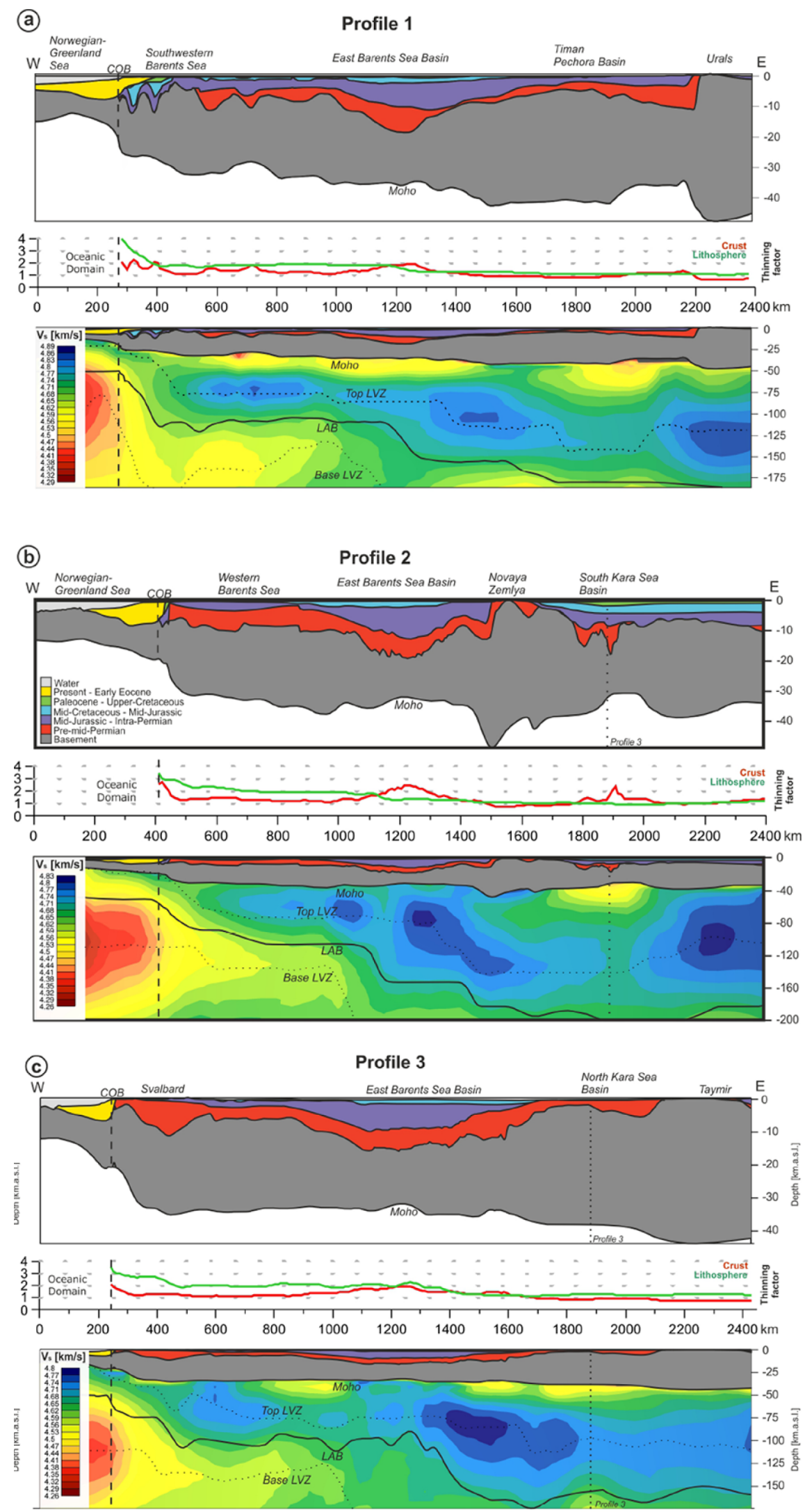

Figure 6. 

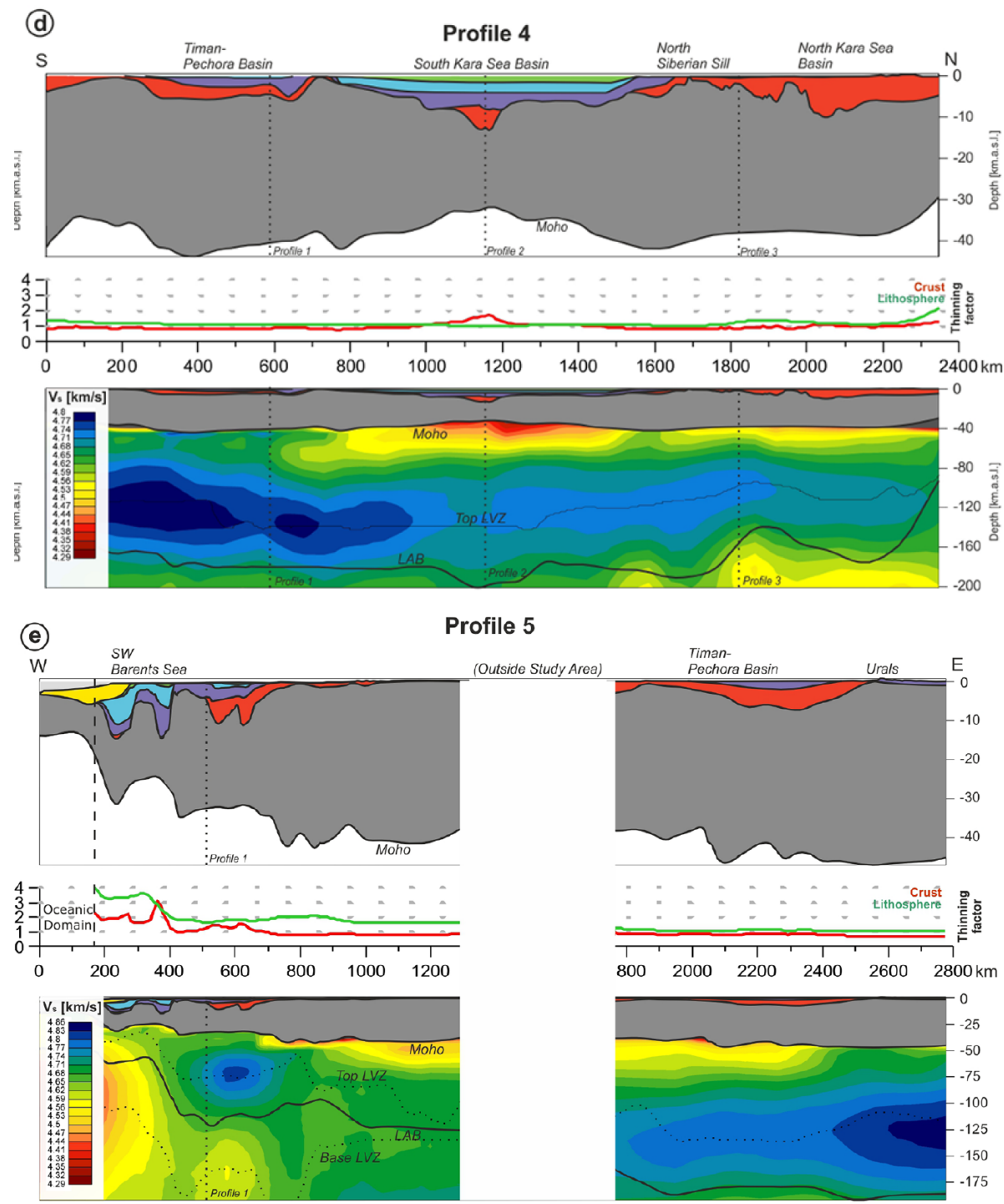

Figure 6. Five profiles illustrating the main geological units and the velocity structure (BARMOD, CUB1.0) on crustal and lithosphere scale (for location see Fig. 1b; LVZ - low velocity zone). The thinning factors are calculated with reference values of 32 and $200 \mathrm{~km}$ for the crystalline basement and the lithospheric mantle, respectively. Vertical exaggeration of the crustal-scale profiles: $5 \times$, vertical exaggeration of the lithosphere-scale profiles: $3 \times$.

\subsection{Mid-Permian to Paleocene}

The mid-Permian to Paleocene interval encompasses three megasequences (mid-Permian-mid-Jurassic, mid-Jurassicmid-Cretaceous, mid-Cretaceous-Paleocene). The thickness configurations of the respective megasequences show that the Barents Sea and Kara Sea region experienced significant subsidence during this time interval. Thereby, the amount and the geometry of the subsidence varies strongly through time in different subdomains, which can be related to certain tectonic and geodynamic developments. While the eastern Barents Sea and the southern Kara Sea are assumed to be affected by compression in response to the Uralian Orogeny in Late Triassic-Early Jurassic times, the western Barents
Sea experienced different extensional phases from late $\mathrm{Pa}$ leozoic to Paleocene times. In response to the locally varying lithospheric configurations and the different prevalent stress fields which most-likely influenced basin formation, the midPermian to Paleocene tectonic evolution of the eastern Barents Sea/southern Kara Sea and of the western Barents Sea are analysed separately in the following.

\subsubsection{Eastern Barents Sea/southern Kara Sea}

The main part of the preserved sedimentary succession in the East Barents Sea basin corresponds to the midPermian-mid-Jurassic megasequence (Fig. 4d) while the two overlying megasequences are distinctively thinner 
(mid-Jurassic-mid-Cretaceous, mid-Cretaceous-Paleocene; Fig. 4b, c). The pre-mid-Jurassic sediment configuration in the southern Kara Sea is less well constrained due to lacking borehole data. However, seismic profiles (Ivanova et al., 2011; Malyshev et al., 2012b; Nikishin et al., 2011; Stoupakova et al., 2011) indicate that a significant amount of mid-Permian to mid-Jurassic sediments is present beneath the southern Kara Sea as also indicated by the model (Figs. 4d, 6b, d). The overlying megasequences (mid-Jurassic-mid-Cretaceous and midCretaceous-Paleocene) also show decreasing thicknesses. This implies that the East Barents Sea basin - and maybe also the southern Kara Sea - experienced strong subsidence in an early tectonic phase followed by weaker subsidence until Paleocene times. The Moho is at comparable depths below both basins (at about $33 \mathrm{~km}$ ) but deepens substantially beneath Novaya Zemlya forming a structural boundary between the two basins (Figs. 5b, 6b).

There are also significant differences between the East Barents Sea basin and the South Kara Sea basin. The preserved mid-Permian-mid-Jurassic megasequence is distinctively thicker in the East Barents Sea basin $(10500 \mathrm{~m}) \mathrm{com}$ pared to the South Kara Sea basin $(6500 \mathrm{~m})$ indicating stronger subsidence west of Novaya Zemlya (Figs. 4d, 6b). In contrast, for the mid-Jurassic-mid Cretaceous and the midCretaceous-Paleocene megasequences the amount of preserved sediments is higher in the South Kara Sea basin (3300 and $1700 \mathrm{~m}$ ) than in the East Barents Sea basin (2200 and $600 \mathrm{~m}$ ). This implies a general eastward shift of major subsidence over Mid-Permian to Paleocene times.

Two major geodynamic events coincide with the deposition of the mid-Permian-mid-Jurassic sedimentary megasequence in the East Barents Sea basin and the South Kara Sea basin. The first event, the Uralian Orogeny, is preserved as a present-day topographic high in concert with a deep Moho along the northern Ural Mountains, the Pai-Khoi and Novaya Zemlya fold-and-thrust belts and the Taimyr region (Figs. 2, 6b; Puchkov, 2009; Steer et al., 1998). The second geodynamic event corresponds to the eruption of flood basalts forming the Siberian Traps at the Permian-Triassic boundary (Cherepanova et al., 2013; Vyssotski et al., 2006). Widespread eruption of flood basalts due to rise of a mantle plume is held responsible to have induced post-Permian thermal subsidence of the West Siberian Basin. The proximity of the East Barents Sea basin and the South Kara Sea basin to the Uralian orogenic root, the West Siberian Basin and the major subsidence during the mid-Permian-mid-Jurassic time interval points a close link between the basin formation and these two geodynamic events.

For the East Barents Sea and South Kara Sea basins, numerous subsidence mechanisms have been postulated in recent years. They include among others (i) a foreland basin evolution (Petrov et al., 2008), (ii) multiphase extension (Ivanova et al., 2006; O'Leary et al., 2004) or (iii) a compressive lithospheric buckling and phase changes (Gac et al., 2012, 2013; Semprich et al., 2010). Whatever the mechanism controlling the strong Late Permian to Early Triassic subsidence, pure extension of the crust appears to be unlikely since traces of pronounced extension in the form of corresponding large normal faults and strong crustal thinning are absent in the basin (Ivanova et al., 2011; Khutorskoi et al., 2008).

A mechanism that might explain the development of the East Barents Sea basin is lithospheric buckling (Gac et al., 2012) that has been discussed also for other basins (Cloetingh and Burov, 2011). An initial extensional phase in Devonian times may have resulted in underplating of magmatic material beneath the present-day East Barents Sea basin. The compressional stress in the course of the Uralian Orogeny could have induced folding of the lithosphere, which may have involved densification of the magmatic body and led to the observed strong subsidence in Late Permian to Early Triassic times (Gac et al., 2012, 2013; Semprich et al., 2010). An important observation is the spatial correlation of the East Barents Sea basin with the extent of the high shear wave velocity anomaly in the lithospheric mantle (Fig. 6a, b; Levshin et al., 2007). The authors relate the anomaly with subduction in the course of the Caledonian and/or Uralian Orogenies. Whatever their origin, the high mantle velocities probably reflect higher densities which, in turn, might have caused deepseated negative buoyancy and shallow subsidence of the East Barents Sea basin.

In contrast to the East Barents Sea basin, the lithospheric mantle below the southern Kara Sea reveals high shear wave velocity anomalies (Fig. 6b, d), which excludes densification of the upper mantle as a driving subsidence mechanism. An alternative mechanism is therefore needed to explain the observed mid-Permian-mid-Jurassic sediment thickness maximum here. A first subsidence stage of the southern Kara Sea is described as rifting-induced with $\mathrm{N}-\mathrm{S}$ oriented grabenlike structures in late Paleozoic to early Mesozoic times due to orogenic collapse (Ivanova et al., 2011; Malyshev et al., 2012b; Nikishin et al., 2011; Stoupakova et al., 2011). The extensional regime is hard to explain with the main compressional phase on Novaya Zemlya up to Late TriassicEarly Jurassic times (Scott and Howard, 2010). Thus, the deep N-S striking graben-like structures in the southern Kara Sea may originate also from a transtensional regime as part of the Uralian Orogeny (Nikishin et al., 2011). Continuous seismic reflections interpreted as sedimentary layers indicate that from the mid-Jurassic on, the South Kara Sea basin adopted a clear bowl-shaped geometry where faulting did not play a significant role for creating accommodation space (Ivanova et al., 2011). To explain the subsidence in the South Kara Sea basin, we might have to widen the view. The mantle plume and related magmatism beneath the West Siberian Basin is thought to have reached also below the South Kara Sea basin (Saunders et al., 2005; Vyssotski et al., 2006) and might thus, have caused thermal cooling following Siberian Traps magmatism. Alternatively, the West Siberian mantle 
plume might have caused negative dynamic topography to its flanks contributing to subsidence across the wider Barents Sea and Kara Sea region. In fact, the BARMOD shear velocity model shows in depths of $50 \mathrm{~km}$ a low-velocity anomaly indicating a thermal anomaly (Fig. 6d; Levshin et al., 2007). However, a remnant from the rifting history or the Siberian plume seems to be unlikely, since the mantle would have thermally re-equilibrated meanwhile. Additionally, the resolution of BARMOD is rather low for the southern Kara Sea region.

\subsubsection{Western Barents Sea}

In contrast to the wide and bowl-shaped structural depression of the eastern Barents Sea, the western Barents Sea is traversed by a system of structural lows and highs of the top crystalline crust (Fig. 4f) with corresponding locally thick sedimentary packages (Fig. 4a-e). These NE-SW- or NNESSW-striking narrow troughs are structurally limited by major late Paleozoic and Mesozoic normal faults that cover the entire western Barents Sea (Fig. 3e, f).

The sediment thickness distribution indicates that rifting and hence subsidence shifted westwards with time, as observable in the sedimentary megasequence which thickens towards the west with decreasing age (Fig. 4b-e). Major rifting in the southwestern Barents Sea continued in midJurassic times giving birth to deep basins (Troms $\varnothing$ Basin, the Sørvestsnaget Basin and the Bjørnøya Basin; Faleide et al., 1993). In the Early Cretaceous, the northern Barents Sea was uplifted - a phenomenon that has been related to the Arctic Large Igneous Province (Basov et al., 2009; Drachev and Saunders, 2006; Maher and Harmon, 2001; Minakov et al., 2012b; Worsley, 2008). The uplifted areas provided a major sediment source for the subsiding basins in the southwestern Barents Sea. Late Cretaceous-Paleocene rifting resulted in the formation of pull-apart basins, and finally in break-up of the Norwegian-Greenland Sea (Faleide et al., 1993, 2008; Libak et al., 2012). The rifting history is also reflected in the subsedimentary configuration in terms of a thinned crystalline crust and lithospheric mantle (Fig. 5b, d) as well as by the rather low velocities of the upper mantle (Fig. 6a, b, c, e).

\subsection{Earliest Eocene to present}

The continental break-up and the opening of the NorwegianGreenland Sea started in Paleocene-Eocene times. Subsequently, the ocean opened progressively northwards along a mega-shear system with assumed rifting and the formation of pull-apart basin in the westernmost Barents Sea (Engen et al., 2008; Faleide et al., 2010). In late Cenozoic times, widespread but locally varying uplift affected the Barents Sea and Kara Sea region and resulted in significant erosion of the uppermost sediments. Accordingly, youngest strata are missing across wide parts of the shelf (Fig. $4 \mathrm{a}-\mathrm{c}$ ). The timing and triggering mechanisms behind this uplift are still un- der debate. Beside isostatic rebound in response to melting of thick Pliocene/Pleistocene ice sheets (Green and Duddy, 2010; Henriksen et al., 2011a), also a tectonic pulse prior to the onset of glaciations has been proposed (Dimakis et al., 1998). In fact, regional synchronous uplift is observed for wider parts of the Arctic which would imply a regional trigger such as the Iceland mantle plume. This deep thermal mantle anomaly is assumed to account for the anomalous shallow seafloor of the NE Atlantic Ocean (Fig. 1; Skogseid, 2014).

In the Barents Sea and Kara Sea region however, strongest Cenozoic uplift occurred on Svalbard which coincides spatially with a thin continental lithosphere and slow shear wave velocities pointing to high temperatures in the upper mantle (Figs. 5d, 6c; Dimakis et al., 1998; Green and Duddy, 2010; Henriksen et al., 2011a; Japsen et al., 2010). Dörr et al. (2013) have stated that Svalbard experienced an isostatic uplift phase around $\sim 36 \mathrm{Ma}$ due to magmatic activity during the formation of the northwards adjoining Yermak Plateau. According to the authors, a second uplift phase may have been induced by thinning of the lithospheric mantle beneath Svalbard. This phenomenon is assumed to be caused by small-scale mantle convection due to the adjacent Knipovich and Gakkel mid-oceanic ridges rather than the effect of plume activity. A recent study by Omang and Kierulf (2011) reveals that Svalbard is still experiencing uplift and that fluctuations of ice sheets cannot explain the observed uplift rates. Consequently, the low-velocity and hot upper mantle may still contribute to present-day vertical movements.

In contrast to the northwestern shelf edge, late Cenozoic uplift and erosion was less pronounced ( 500-1000 m) in the eastern Barents Sea (Henriksen et al., 2011a; Sobolev, 2012). Thereby, the area affected by the least erosion correlates spatially with the outline of the East Barents Sea basin but also with a domain where highest velocities in the lithospheric mantle (Fig. 6b, c) are observed. Consequently, the high velocities which are associated with a strong lithosphere may have contributed not only to the formation of the East Barents Sea basin in Paleozoic/Mesozoic times but may have also prevented significant uplift in late Cenozoic times.

\section{Summary and conclusions}

We have constructed a 3-D structural model of the greater Barents Sea and Kara Sea region that resolves the first-order characteristics of its sedimentary cover, its crystalline crust as well as of its lithospheric mantle. A large amount of multidisciplinary geophysical and geological data were integrated, to model the best-possible structural configuration of the following continental subdomains: (1) the northern Kara Sea, (2) the southern Kara Sea, (3) the eastern Barents Sea and (4) the western Barents Sea.

1. The North Kara Sea basin is covered mainly by pre-midPermian sediments indicating that its major subsidence 
phase was prior to the adjacent sedimentary basins. The related sediment maximum is separated from the Barents Sea by a NW-striking thickened crystalline crust which may have originated from the late Neoproterozoic Timanian Orogeny.

2. The southern Kara Sea reveals a rather independent evolution from its northern counterpart. A distinctively deeper LAB delimits the sedimentary basin from the Barents Sea and may suggest an affiliation with the Siberian plate. The South Kara Sea basin lacks major pre-mid-Permian sediments, but has accumulated the major part of its sedimentary infill in mid-Permian to earliest Eocene times. Thereby, the younger sedimentary megasequences are thinner, implying a decaying subsidence with time that was either of thermal origin related to magmatism or due to negative dynamic topography in the course of the West Siberian mantle plume.

3. Thickest sediments in the eastern Barents Sea have been preserved from the mid-Permian-mid-Jurassic megasequence indicating strong subsidence back then. The sedimentary succession in the East Barents Sea basin shows no larger extensional faults but is coinciding spatially with anomalously high shear wave velocities in the lithospheric mantle that may have played an essential role during the evolution of this sedimentary basin. Lithospheric buckling with associated phase transitions (Gac et al., 2012, 2013; Semprich et al., 2010) could be one explanation the intense subsidence in Permian to Triassic times. The high-velocity anomaly in the lithospheric mantle beneath the eastern Barents Sea may have contributed to accelerated Permian to Triassic subsidence and might be responsible for less intense uplift of the eastern Barents Sea in late Cenozoic times.

4. The southwestern Barents Sea exhibits a classical rift system with major extensional faults. The amounts of sediments deposited as megasequences increase with time towards the present-day COB indicating a westward shift in rifting. The shallow Moho and LAB as well as low seismic shear wave velocities in the mantle indicating high mantle temperatures are consistent with the assumption of a rift scenario. The continental LAB is shallowest below Svalbard and the northwestern Barents Sea where strong late Cenozoic uplift and volcanism are observed.

In the next steps, the 3-D structural model will be tested against independent observables such as gravity and temperature. Constraining the present-day lithosphere-scale 3-D thermal field provides implications about the regional strength of the lithosphere and thus, will be essential to further unravel the evolution of the Barents Sea and Kara Sea region and the mechanisms behind subsidence and uplift.
Acknowledgements. We acknowledge financial support by Statoil for parts of the work reported on here. Also we would like to thank for constructive discussions with colleagues involved in the BarMod project currently funded by the Research Council of Norway and Statoil, and in the CALE project.

The service charges for this open access publication have been covered by a Research Centre of the Helmholtz Association.

Edited by: R. Carbonell

\section{References}

Allen, P. A. and Allen, J. R.: Basin Analysis: Principles and Application to Petroleum Play Assessment, 3rd Edn., WileyBlackwell, 2013.

Aplonov, S. V., Shmelev, G. B., and Krasnov, D. K.: Geodynamics of the Barents-Kara Shelf: Geophysical Evidence, Geotectonics+, 30, 309-326, 1996.

Artyushkov, E.: The formation mechanism of the Barents basin, Russ. Geol. Geophys., 46, 700-713, 2005.

Barrère, C., Ebbing, J., and Gernigon, L.: Offshore prolongation of Caledonian structures and basement characterisation in the western Barents Sea from geophysical modelling, Tectonophysics, 470, 71-88, doi:10.1016/j.tecto.2008.07.012, 2009.

Basov, V. A., Ebbing, J., Gernigon, L., Korchinskaya, M. V., Koren, T., Kosteva, N. V., Kotljar, G. V., Larssen, G. B., Litvinova, T., Negrov, O. B., Olesen, O., Pascal, C., Pchelina, T. M., Petrov, O. V., Petrov, Y. O., Sjulstad, H.-I., Smelror, M., Sobolev, N. N., Vasiliev, V., and Werner, S. C.: Geological history of the Barents Sea, edited by: Smelror, M., Petrov, O., Larssen, G., and Werner, S., Geological Survey of Norway, Trondheim, Norway, 1-138, 2009.

Bogdanova, S. V., Bingen, B., Gorbatschev, R., Kheraskova, T. N., Kozlov, V. I., Puchkov, V. N., and Volozh, Y. A.: The East European Craton (Baltica) before and during the assembly of Rodinia, Precambrian Res., 160, 23-45, doi:10.1016/j.precamres.2007.04.024, 2008.

Breivik, A. J., Faleide, J. I., and Gudlaugsson, S. T.: Southwestern Barents Sea margin: late Mesozoic sedimentary basins and crustal extension, Tectonophysics, 293, 21-44, doi:10.1016/S0040-1951(98)00073-0, 1998.

Breivik, A., Verhoef, J., and Faleide, J.: Effect of thermal contrasts on gravity modeling at passive margins: results from the western Barents Sea, J. Geophys. Res., 104, 15293-15311, doi:10.1029/1998JB900022, 1999.

Breivik, A. J., Mjelde, R., Grogan, P., Shimamura, H., Murai, Y., and Nishimura, Y.: Crustal structure and transform margin development south of Svalbard based on ocean bottom seismometer data, Tectonophysics, 369, 37-70, doi:10.1016/S00401951(03)00131-8, 2003.

Breivik, A. J., Mjelde, R., Grogan, P., Shimamura, H., Murai, Y., and Nishimura, Y.: Caledonide development offshore-onshore Svalbard based on ocean bottom seismometer, conventional seismic, and potential field data, Tectonophysics, 401, 79-117, doi:10.1016/j.tecto.2005.03.009, 2005. 
Brekhuntsov, A. M., Monastyrev, B. V., and Nesterov, I. I.: Distribution patterns of oil and gas accumulations in West Siberia, Russ. Geol. Geophys.+, 52, 781-791, doi:10.1016/j.rgg.2011.07.004, 2011.

Cherepanova, Y., Artemieva, I. M., Thybo, H., and Chemia, Z.: Crustal structure of the Siberian craton and the West Siberian basin: An appraisal of existing seismic data, Tectonophysics, 609, 154-183, doi:10.1016/j.tecto.2013.05.004, 2013.

Clark, S. A., Faleide, J. I., Hauser, J., Ritzmann, O., Mjelde, R., Ebbing, J., Thybo, H., and Flüh, E.: Stochastic velocity inversion of seismic reflection/refraction traveltime data for rift structure of the southwest Barents Sea, Tectonophysics, 593, 135-150, doi:10.1016/j.tecto.2013.02.033, 2013a.

Clark, S. A., Glorstad-Clark, E., Faleide, J. I., Schmid, D., Hartz, E. H., and Fjeldskaar, W.: Southwest Barents Sea rift basin evolution: comparing results from backstripping and time-forward modelling, Basin Res., 25, 1-17, doi:10.1111/bre.12039, 2013b.

Cloetingh, S. and Burov, E.: Lithospheric folding and sedimentary basin evolution: a review and analysis of formation mechanisms, Basin Res., 23, 257-290, doi:10.1111/j.13652117.2010.00490.x, 2011.

Czuba, W., Grad, M., Mjelde, R., Guterch, A., Libak, A., Krüger, F., Murai, Y., and Schweitzer, J.: Continent-ocean-transition across a trans-tensional margin segment: off Bear Island, Barents Sea, Geophys. J. Int., 184, 541-554, doi:10.1111/j.1365246X.2010.04873.x, 2011.

Dahl-Jensen, T., Larsen, T. B., Woelbern, I., Bach, T., Hanka, W., Kind, R., Gregersen, S., Mosegaard, K., Voss, P., and Gudmundsson, O.: Depth to Moho in Greenland: receiver-function analysis suggests two Proterozoic blocks in Greenland, Earth Planet. Sc. Lett., 205, 379-393, doi:10.1016/S0012-821X(02)01080-4, 2003.

Dick, H. J. B., Lin, J., and Schouten, H.: An ultraslowspreading class of ocean ridge, Nature, 426, 405-412, doi:10.1038/nature02128, 2003.

Dimakis, P., Braathen, B. I., Faleide, J. I., Elverhøi, A., and Gudlaugsson, S. T.: Cenozoic erosion and the preglacial uplift of the Svalbard-Barents Sea region, Tectonophysics, 300, 311-327, doi:10.1016/S0040-1951(98)00245-5, 1998.

Dörr, N., Clift, P. D., Lisker, F., and Spiegel, C.: Why is Svalbard an island? Evidence for two-stage uplift, magmatic underplating, and mantle thermal anomalies, Tectonics, 32, 473-486, doi:10.1002/tect.20039, 2013.

Dörr, N., Lisker, F., Clift, P. D., Carter, A., Gee, D. G., Tebenkov, A. M., and Spiegel, C.: Late Mesozoic-Cenozoic exhumation history of northern Svalbard and its regional significance: Constraints from apatite fission track analysis, Tectonophysics, 514517, 81-92, doi:10.1016/j.tecto.2011.10.007, 2012.

Drachev, S. and Saunders, A.: The Early Cretaceous Arctic LIP: its geodynamic setting and implications for Canada Basin opening, in: Proceedings of the Fourth International Conference on Arctic Margins, US Department of the Interior, Anchorage, 216-223, 2006

Drachev, S. S.: Chapter 25 Tectonic setting, structure and petroleum geology of the Siberian Arctic offshore sedimentary basins, Geological Society, London, Memoirs, 35, 369-394, doi:10.1144/M35.25, 2011.
Dubinin, E. P., Kokhan, A. V., and Sushchevskaya, N. M.: Tectonics and magmatism of ultraslow spreading ridges, Geotectonics, 47, 131-155, doi:10.1134/S0016852113030023, 2013.

Eaton, D. W., Darbyshire, F., Evans, R. L., Grütter, H., Jones, A. G., and Yuan, X.: The elusive lithosphereasthenosphere boundary (LAB) beneath cratons, Lithos, 109, 122, doi:10.1016/j.lithos.2008.05.009, 2009.

Engen, Ø., Frazer, L. N., Wessel, P., and Faleide, J. I.: Prediction of sediment thickness in the Norwegian-Greenland Sea from gravity inversion, J. Geophys. Res., 111, B11403, doi:10.1029/2005JB003924, 2006.

Engen, Ø., Faleide, J. I., and Dyreng, T. K.: Opening of the Fram Strait gateway: A review of plate tectonic constraints, Tectonophysics, 450, 51-69, doi:10.1016/j.tecto.2008.01.002, 2008.

Engen, Ø., Gjengedal, J. A., Faleide, J. I., Kristoffersen, Y., and Eldholm, O.: Seismic stratigraphy and sediment thickness of the Nansen Basin, Arctic Ocean, Geophys. J. Int., 176, 805-821, doi:10.1111/j.1365-246X.2008.04028.x, 2009.

Faleide, J. I., Vågnes, E., and Gudlaugsson, S. T.: Late MesozoicCenozoic evolution of the south-western Barents Sea in a regional rift-shear tectonic setting, Mar. Petrol. Geol., 10, 186-214, doi:10.1016/0264-8172(93)90104-Z, 1993.

Faleide, J. I., Solheim, A., Fiedler, A., Hjelstuen, B. O., Andersen, E. S., and Vanneste, K.: Late Cenozoic evolution of the western Barents Sea-Svalbard continental margin, Global Planet Change, 12, 53-74, doi:10.1016/0921-8181(95)00012-7, 1996.

Faleide, J. I., Tsikalas, F., Breivik, A. J., Mjelde, R., Ritzmann, O., Engen, O., Wilson, J., and Eldholm, O.: Structure and evolution of the continental margin off Norway and the Barents Sea, Episodes, 31, 82-91, 2008.

Faleide, J. I., Bjørlykke, K., and Gabrielsen, R. H.: Geology of the Norwegian Continental Shelf, in: Petroleum Geoscience: From Sedimentary Environments to Rock Physics, edited by: Bjørlykke, K., Springer-Verlag, Berlin, Heidelberg, 467-499, doi:10.1007/978-3-642-02332-3_22, 2010.

Fiedler, A. and Faleide, J. I.: Cenozoic sedimentation along the southwestern Barents Sea margin in relation to uplift and erosion of the shelf, Global Planet. Change, 12, 75-93, doi:10.1016/0921-8181(95)00013-5, 1996.

Fischer, K. M., Ford, H. A., Abt, D. L., and Rychert, C. A.: The Lithosphere-Asthenosphere Boundary, Annu. Rev. Earth Pl. Sc., 38, 551-575, doi:10.1146/annurev-earth-040809-152438, 2010.

Gac, S., Huismans, R. S., Podladchikov, Y. Y., and Faleide, J. I.: On the origin of the ultradeep East Barents Sea basin, J. Geophys. Res., 117, B04401, doi:10.1029/2011JB008533, 2012.

Gac, S., Huismans, R. S., Simon, N. S. C., Podladchikov, Y. Y., and Faleide, J. I.: Formation of intracratonic basins by lithospheric shortening and phase changes: a case study from the ultra-deep East Barents Sea basin, Terra Nova, 25, 459-464, doi:10.1111/ter.12057, 2013.

Gee, D. G. and Pease, V.: The Neoproterozoic Timanide Orogen of eastern Baltica: introduction, Geological Society, London, Memoirs, 30, 1-3, doi:10.1144/GSL.MEM.2004.030.01.01, 2004.

Gee, D. G., Beliakova, L., and Pease, V.: New, single zircon (Pbevaporation) ages from Vendian intrusions in the basement beneath the Pechora Basin, northeastern Baltica, Polarforschung, Bremerhaven, Alfred Wegener Institute for Polar and Marine Research \& German Society of Polar Research, 68, 161-170, 2000 
Gee, D. G., Bogolepova, O. K., and Lorenz, H.: The Timanide, Caledonide and Uralide orogens in the Eurasian high Arctic, and relationships to the palaeo-continents Laurentia, Baltica and Siberia, Geological Society, London, Memoirs, 32, 507-520, doi:10.1144/GSL.MEM.2006.032.01.31, 2006.

Gernigon, L. and Brönner, M.: Late Palaeozoic architecture and evolution of the southwestern Barents Sea: insights from a new generation of aeromagnetic data, Journal of the Geological Society, 169, 449-459, doi:10.1144/0016-76492011-131, 2012.

Gernigon, L., Brönner, M., Roberts, D., Olesen, O., Nasuti, A., and Yamasaki, T.: Crustal and basin evolution of the southwestern Barents Sea: From Caledonian orogeny to continental breakup, Tectonics, 33, 347-373, doi:10.1002/2013TC003439, 2014.

Glebovsky, V. Y., Kaminsky, V. D., Minakov, A. N., Merkur'ev, S. A., Childers, V. A., and Brozena, J. M.: Formation of the Eurasia Basin in the Arctic Ocean as inferred from geohistorical analysis of the anomalous magnetic field, Geotectonics, 40, 263-281, doi:10.1134/S0016852106040029, 2006.

Glørstad-Clark, E.: Basin analysis in the western Barents Sea area: the interplay between accommodation space and depositional systems, University of Oslo, Oslo, doi:10.1016/j.marpetgeo.2010.02.008, 2011.

Gradstein, F. M., Ogg, J. G., and Hilgen, F. J.: On The Geologic Time Scale, Newsletters Stratigr., 45, 171-188, doi:10.1127/0078-0421/2012/0020, 2012.

Gramberg, I., Verba, V., and Verba, M.: Sedimentary Cover Thickness Map-Sedimentary Basins in the Arctic, Polarforschung, 69, 243-249, 2001.

Green, P. and Duddy, I.: Synchronous exhumation events around the Arctic including examples from Barents Sea and Alaska North Slope, Petroleum Geology Conference series, 7, 633-644, doi:10.1144/0070633, 2010.

Gudlaugsson, S., Faleide, J. I., Johansen, S. E., and Breivik, A. J.: Late Palaeozoic structural development of the South-western Barents Sea, Mar. Petrol. Geol., 15, 73-102, doi:10.1016/S02648172(97)00048-2, 1998

Gung, Y., Panning, M., and Romanowicz, B.: Global anisotropy and the thickness of continents, Nature, 422, 707-711, doi:10.1038/nature01559, 2003.

Hauser, J., Dyer, K. M., Pasyanos, M. E., Bungum, H., Faleide, J. I., Clark, S. A., and Schweitzer, J.: A probabilistic seismic model for the European Arctic, J. Geophys. Res., 116, 1-17, doi:10.1029/2010JB007889, 2011

Heine, C., Müller, R. D., Steinberger, B., and Torsvik, T. H.: Subsidence in intracontinental basins due to dynamic topography, Phys. Earth Planet. In., 171, 252-264, doi:10.1016/j.pepi.2008.05.008, 2008.

Henriksen, E., Bjornseth, H. M., Hals, T. K., Heide, T., Kiryukhina, T., Klovjan, O. S., Larssen, G. B., Ryseth, A. E., Ronning, K., Sollid, K., and Stoupakova, A.: Uplift and erosion of the greater Barents Sea: impact on prospectivity and petroleum systems, Geological Society, London, Memoirs, 35, 271-281, doi:10.1144/M35.17, 2011a.

Henriksen, E., Ryseth, A. E., Larssen, G. B., Heide, T., Ronning, K., Sollid, K., and Stoupakova, A. V.: Tectonostratigraphy of the greater Barents Sea: implications for petroleum systems, Geological Society, London, Memoirs, 35, 163-195, doi:10.1144/M35.10, 2011b.
Hjelstuen, B., Elverhøi, A., and Faleide, J.: Cenozoic erosion and sediment yield in the drainage area of the Storfjorden Fan, Global Planet. Change, 12, 95-117, doi:10.1016/0921-8181(95)000143, 1996.

Huang, P. Y. and Solomon, S. C.: Centroid Depths of Mid-Ocean Ridge Earthquakes: Dependence on Spreading Rate, J. Geophys. Res., 93, 13445-13477, doi:10.1029/JB093iB11p13445, 1988.

Ivanova, N. M., Sakoulina, T. S., and Roslov, Y. V.: Deep seismic investigation across the Barents-Kara region and Novozemelskiy Fold Belt (Arctic Shelf), Tectonophysics, 420, 123-140, doi:10.1016/j.tecto.2006.01.011, 2006.

Ivanova, N. M., Sakulina, T. S., Belyaev, I. V., Matveev, Y. I., and Roslov, Y. V.: Depth model of the Barents and Kara seas according to geophysical surveys results, Geological Society, London, Memoirs, 35, 209-221, doi:10.1144/M35.12, 2011.

Jakobsson, M., Mayer, L., Coakley, B., Dowdeswell, J. A., Forbes, S., Fridman, B., Hodnesdal, H., Noormets, R., Pedersen, R., Rebesco, M., Schenke, H. W., Zarayskaya, Y., Accettella, D., Armstrong, A., Anderson, R. M., Bienhoff, P., Camerlenghi, A., Church, I., Edwards, M., Gardner, J. V., Hall, J. K., Hell, B., Hestvik, O., Kristoffersen, Y., Marcussen, C., Mohammad, R., Mosher, D., Nghiem, S. V., Pedrosa, M. T., Travaglini, P. G., and Weatherall, P.: The International Bathymetric Chart of the Arctic Ocean (IBCAO) Version 3.0, Geophys. Res. Lett., 39, L12609, doi:10.1029/2012GL052219, 2012.

Japsen, P., Green, P. F., Bonow, J. M., Rasmussen, E. S., Chalmers, J. A., and Kjennerud, T.: Episodic uplift and exhumation along North Atlantic passive margins: implications for hydrocarbon prospectivity, Petroleum Geology Conference series, 7, 9791004, doi:10.1144/0070979, 2010.

Johansen, S. E., Ostisty, B. K., Birkeland, Ø., Fedorovsky, Y. F., Martirosjan, V. N., Christensen, O. B., Cheredeev, S. I., Ignatenko, E. A., and Margulis, L. S.: Hydrocarbon potential in the Barents Sea region: play distribution and potential, in Norwegian Petroleum Society Special Publications, 2, 273-320, 1993.

Karato, S.: On the origin of the asthenosphere, Earth Planet. Sc. Lett., 321-322, 95-103, doi:10.1016/j.epsl.2012.01.001, 2012.

Khutorskoi, M. D., Viskunova, K. G., Podgornykh, L. V., Suprunenko, O. I., and Akhmedzyanov, V. R.: A temperature model of the crust beneath the Barents Sea: Investigations along geotraverses, Geotectonics, 42, 125-136, doi:10.1134/S0016852108020039, 2008.

Klimenko, S. S., Anischenko, L. A., and Antoshkina, A. I.: The Timan-Pechora sedimentary basin: Palaeozoic reef formations and petroleum systems, Geological Society, London, Memoirs, 35, 223-236, doi:10.1144/M35.13, 2011.

Knies, J., Matthiessen, J., Vogt, C., Laberg, J. S., Hjelstuen, B. O., Smelror, M., Larsen, E., Andreassen, K., Eidvin, T., and Vorren, T. O.: The Plio-Pleistocene glaciation of the Barents Sea-Svalbard region: a new model based on revised chronostratigraphy, Quaternary Sci. Rev., 28, 812-829, doi:10.1016/j.quascirev.2008.12.002, 2009.

Kontorovich, A. E., Epov, M. I., Burshtein, L. M., Kaminskii, V. D., Kurchikov, A. R., Malyshev, N. A., Prischepa, O. M., Safronov, A. F., Stupakova, A. V., and Suprunenko, O. I.: Geology and hydrocarbon resources of the continental shelf in Russian Arctic seas and the prospects of their development, Russ. Geol. Geophys.+, 51, 3-11, doi:10.1016/j.rgg.2009.12.003, 2010. 
Koptev, A. I. and Ershov, A. V.: Thermal thickness of the Earth's lithosphere: a numerical model, Moscow University Geology Bulletin, 66, 323-330, doi:10.3103/S014587521105005X, 2011.

Kostyuchenko, S., Sapozhnikov, R., Egorkin, A., Gee, D. G., Berzin, R., and Solodilov, L.: Crustal structure and tectonic model of northeastern Baltica, based on deep seismic and potential field data, Geological Society, London, Memoirs, 32, 521539, doi:10.1144/GSL.MEM.2006.032.01.32, 2006.

Kumar, P., Kind, R., Hanka, W., Wylegalla, K., Reigber, C., Yuan, X., Woelbern, I., Schwintzer, P., Fleming, K., Dahl-Jensen, T., Larsen, T. B., Schweitzer, J., Priestley, K., Gudmundsson, O., and Wolf, D.: The lithosphere-asthenosphere boundary in the North-West Atlantic region, Earth Planet. Sc. Lett., 236, 249257, doi:10.1016/j.epsl.2005.05.029, 2005.

Laberg, J. S. and Vorren, T. O.: Late Weichselian submarine debris flow deposits on the Bear Island Trough Mouth Fan, Mar. Geol., 127, 45-72, doi:10.1016/0025-3227(95)00055-4, 1995.

Laberg, J. S. and Vorren, T. O.: Flow behaviour of the submarine glacigenic debris flows on the Bear Island Trough Mouth Fan, western Barents Sea, Sedimentology, 47, 11051117, doi:10.1046/j.1365-3091.2000.00343.x, 2000.

Levshin, A. L., Schweitzer, J., Weidle, C., Shapiro, N. M., and Ritzwoller, M. H.: Surface wave tomography of the Barents Sea and surrounding regions, Geophys. J. Int., 170, 441-459, doi:10.1111/j.1365-246X.2006.03285.x, 2007.

Libak, A., Eide, C. H., Mjelde, R., Keers, H., and Flüh, E. R.: From pull-apart basins to ultraslow spreading: Results from the western Barents Sea Margin, Tectonophysics, 514-517, 44-61, doi:10.1016/j.tecto.2011.09.020, 2012.

Ljones, F., Kuwano, A., Mjelde, R., Breivik, A., Shimamura, H., Murai, Y., and Nishimura, Y.: Crustal transect from the North Atlantic Knipovich Ridge to the Svalbard Margin west of Hornsund, Tectonophysics, 378, 17-41, doi:10.1016/j.tecto.2003.10.003, 2004.

Lorenz, H., Männik, P., Gee, D., and Proskurnin, V.: Geology of the Severnaya Zemlya Archipelago and the North Kara Terrane in the Russian high Arctic, Int. J. Earth Sci., 97, 519-547, doi:10.1007/s00531-007-0182-2, 2007.

Maher, J. and Harmon, D.: Manifestations of the Cretaceous High Arctic Large Igneous Province in Svalbard, J. Geol., 109, 91104, doi:10.1086/317960, 2001.

Malyshev, N. A., Nikishin, V. A., Nikishin, A. M., Obmetko, V. V., Martirosyan, V. N., Kleshchina, L. N., and Reydik, Y. V.: A new model of the geological structure and evolution of the North Kara Sedimentary Basin, Dokl. Earth Sci., 445, 791-795, doi:10.1134/S1028334X12070057, 2012a.

Malyshev, N. A., Nikishin, V. A., Obmetko, V. V., Ikhsanov, B. I., Reydik, Y. V., Sitar, K. A., and Shapabaeva, D. S.: Geological Structure and Petroleum System of South Kara Basin, in: 5th EAGE St. Petersburg International Conference and Exhibition on Geosciences - Making the Most of the Earths Resources, Saint Petersburg 2012, doi:10.3997/2214-4609.20143593, 2012b.

Marello, L., Ebbing, J., and Gernigon, L.: Basement inhomogeneities and crustal setting in the Barents Sea from a combined 3D gravity and magnetic model, Geophys. J. Int., 193, 557-584, doi:10.1093/gji/ggt018, 2013.

McKenzie, D. and Priestley, K.: The influence of lithospheric thickness variations on continental evolution, Lithos, 102, 1-11, doi:10.1016/j.lithos.2007.05.005, 2008.
Minakov, A., Faleide, J. I., Glebovsky, V. Y., and Mjelde, R.: Structure and evolution of the northern Barents-Kara Sea continental margin from integrated analysis of potential fields, bathymetry and sparse seismic data, Geophys. J. Int., 188, 79102, doi:10.1111/j.1365-246X.2011.05258.x, 2012a.

Minakov, A., Mjelde, R., Faleide, J. I., Flueh, E. R., Dannowski, A., and Keers, H.: Mafic intrusions east of Svalbard imaged by active-source seismic tomography, Tectonophysics, 518-521, 106-118, doi:10.1016/j.tecto.2011.11.015, 2012b.

Müller, R. D., Sdrolias, M., Gaina, C., and Roest, W. R.: Age, spreading rates, and spreading asymmetry of the world's ocean crust, Geochem. Geophy. Geosy., 9, Q04006, doi:10.1029/2007GC001743, 2008.

Myklebust, R.: Magentic mapping of the Barents Sea (MMBS)Unpublished Interpretation report, 1994.

Nikishin, A. M., Ziegler, P. A., Stephenson, R. A., Cloetingh, S., Furne, A. V., Fokin, P. A., Ershov, A. V, Bolotov, S. N., Korotaev, M. V., and Alekseev, A. S.: Late Precambrian to Triassic history of the East European Craton: dynamics of sedimentary basin evolution, Tectonophysics, 268, 23-63, 1996.

Nikishin, A. M., Ziegler, P. A., Abbott, D., Brunet, M.-F., and Cloetingh, S.: Permo-Triassic intraplate magmatism and rifting in Eurasia: implications for mantle plumes and mantle dynamics, Tectonophysics, 351, 3-39, doi:10.1016/S0040-1951(02)001233, 2002 .

Nikishin, V. A., Malyshev, N. A., Nikishin, A. M., and Obmetko, V. V.: The Late Permian-Triassic system of rifts of the South Kara sedimentary basin, Moscow University Geology Bulletin, 66, 377-384, doi:10.3103/S0145875211060093, 2011.

O’Leary, N., White, N., Tull, S., Bashilov, V., Kuprin, V., Natapov, L., and Macdonald, D.: Evolution of the TimanPechora and South Barents Sea basins, Geol. Mag., 141, 141-160, doi:10.1017/S0016756804008908, 2004.

Omang, O. C. D. and Kierulf, H. P.: Past and present-day ice mass variation on Svalbard revealed by superconducting gravimeter and GPS measurements, Geophys. Res. Lett., 38, L22304, doi:10.1029/2011GL049266, 2011.

Otto, S. C. and Bailey, R. J.: Tectonic evolution of the northern Ural Orogen, J. Geol. Soc. London, 152, 903-906, doi:10.1144/GSL.JGS.1995.152.01.03, 1995.

Pease, V. and Scott, R. A.: Crustal affinities in the Arctic Uralides, northern Russia: significance of detrital zircon ages from Neoproterozoic and Palaeozoic sediments in Novaya Zemlya and Taimyr, J. Geol. Soc. London, 166, 517-527, doi:10.1144/001676492008-093, 2009.

Petrov, O. V., Sobolev, N. N., and Koren, T. N.: Palaeozoic and Early Mesozoic evolution of the East Barents and Kara Seas sedimentary basins, Norweg. J. Geol., 88, 227-234, 2008.

Piskarev, A. and Shkatov, M.: Energy potential of the Russian Arctic Seas - Choice of Development Strategy, 1st Edn., Elsevier, 2012.

Priestley, K. and McKenzie, D.: The thermal structure of the lithosphere from shear wave velocities, Earth Planet. Sc. Lett., 244 285-301, doi:10.1016/j.eps1.2006.01.008, 2006.

Puchkov, V. N.: The evolution of the Uralian orogen, Geological Society, London, Special Publications, 327, 161-195, doi:10.1144/SP327.9, 2009.

Reichow, M. K., Saunders, A. D., White, R. V., Al'Mukhamedov, A. I., and Medvedev, A. Y.: Geochemistry and petrogenesis 
of basalts from the West Siberian Basin: an extension of the Permo-Triassic Siberian Traps, Russia, Lithos, 79, 425-452, doi:10.1016/j.lithos.2004.09.011, 2005.

Ritzmann, O. and Faleide, J. I.: Caledonian basement of the western Barents Sea, Tectonics, 26, 1-20, doi:10.1029/2006TC002059, 2007.

Ritzmann, O. and Faleide, J. I.: The crust and mantle lithosphere in the Barents Sea/Kara Sea region, Tectonophysics, 470, 89-104, doi:10.1016/j.tecto.2008.06.018, 2009.

Ritzmann, O., Jokat, W., Mjelde, R., and Shimamura, H.: Crustal structure between the Knipovich Ridge and the Van Mijenfjorden (Svalbard), Mar. Geophys. Res., 23, 379-401, doi:10.1023/B:MARI.0000018168.89762.a4, 2002.

Ritzmann, O., Jokat, W., Czuba, W., Guterch, A., Mjelde, R., and Nishimura, Y.: A deep seismic transect from Hovgård Ridge to northwestern Svalbard across the continental-ocean transition: A sheared margin study, Geophys. J. Int., 157, 683-702, doi:10.1111/j.1365-246X.2004.02204.x, 2004.

Ritzmann, O., Maercklin, N., Inge Faleide, J., Bungum, H., Mooney, W. D., Detweiler, S. T., Faleide, J. I., and Bungurm, H.: A three-dimensional geophysical model of the crust in the Barents Sea region: model construction and basement characterization, Geophys. J. Int., 170, 417-435, doi:10.1111/j.1365246X.2007.03337.x, 2007.

Roberts, D. and Siedlecka, A.: Timanian orogenic deformation along the northeastern margin of Baltica, Northwest Russia and Northeast Norway, and Avalonian-Cadomian connections, Tectonophysics, 352, 169-184, doi:10.1016/S00401951(02)00195-6, 2002.

Saunders, A. D., England, R. W., Reichow, M. K., and White, R. V.: A mantle plume origin for the Siberian traps: uplift and extension in the West Siberian Basin, Russia, Lithos, 79, 407-424, doi:10.1016/j.lithos.2004.09.010, 2005

Sauter, D., Sloan, H., Cannat, M., Goff, J., Patriat, P., Schaming, M., and Roest, W. R.: From slow to ultra-slow: How does spreading rate affect seafloor roughness and crustal thickness?, Geology, 39, 911-914, doi:10.1130/G32028.1, 2011.

Scott, R. and Howard, J.: Offset and curvature of the Novaya Zemlya fold-and-thrust belt, Arctic Russia, Petroleum Geology Conference series, 7, 645-657, doi:10.1144/0070645, 2010.

Semprich, J., Simon, N. S. C., and Podladchikov, Y. Y.: Density variations in the thickened crust as a function of pressure, temperature, and composition, Int. J. Earth Sci., 99, 1487-1510, doi:10.1007/s00531-010-0557-7, 2010.
Shapiro, N. M. and Ritzwoller, M. H.: Monte-Carlo inversion for a global shear-velocity model of the crust and upper mantle, Geophys. J. Int., 151, 88-105, doi:10.1046/j.1365246X.2002.01742.x, 2002.

Skilbrei, J. R.: Interpretation of depth to the magnetic basement in the northern Barents Sea (south of Svalbard), Tectonophysics, 200, 127-141, doi:10.1016/0040-1951(91)90010-P, 1991.

Skogseid, J.: Mantle plume related dynamic uplift and plate kinematics: The NE Atlantic case with global implications, EGU General Assembly, Vienna, Austria, 27 April-2 May, EGU201416896, 2014.

Sobolev, P.: Cenozoic uplift and erosion of the Eastern Barents Sea - constraints from offshore well data and the implication for petroleum system modelling, Z. Dtsch. Ges. Geowiss., 163, 309324, doi:10.1127/1860-1804/2012/0163-0323, 2012.

Steer, D. N., Knapp, J. H., Brown, L. D., Echtler, H. P., Brown, D. L., and Berzin, R.: Deep structure of the continental lithosphere in an unextended orogen: An explosive-source seismic reflection profile in the Urals (Urals Seismic Experiment and Integrated Studies (URSEIS 1995)), Tectonics, 17, 143-157, doi:10.1029/97TC03056, 1998.

Stoupakova, A. V., Henriksen, E., Burlin, Y. K., Larsen, G. B., Milne, J. K., Kiryukhina, T. A., Golynchik, P. O., Bordunov, S. I., Ogarkova, M. P., and Suslova, A. A.: The geological evolution and hydrocarbon potential of the Barents and Kara shelves, Geological Society, London, Memoirs, 35, 325-344, doi:10.1144/M35.21, 2011.

Turcotte, D. L. and Schubert, G.: Geodynamics, Cambridge University Press, Cambridge, UK, 2002.

Voss, M. and Jokat, W.: Continent-ocean transition and voluminous magmatic underplating derived from P-wave velocity modelling of the East Greenland continental margin, Geophys. J. Int., 170, 580-604, doi:10.1111/j.1365-246X.2007.03438.x, 2007.

Voss, M. and Jokat, W.: From Devonian extensional collapse to early Eocene continental break-up: an extended transect of the Kejser Franz Joseph Fjord of the East Greenland margin, Geophys. J. Int., 177, 743-754, doi:10.1111/j.1365246X.2008.04076.x, 2009.

Vyssotski, A. V., Vyssotski, V. N., and Nezhdanov, A. A.: Evolution of the West Siberian Basin, Mar. Petrol. Geol., 23, 93-126, doi:10.1016/j.marpetgeo.2005.03.002, 2006.

Worsley, D.: The post-Caledonian development of Svalbard and the western Barents Sea, Polar Res., 27, 298-317, doi:10.1111/j.1751-8369.2008.00085.x, 2008.

Zhang, Y. and Lay, T.: Evolution of oceanic upper mantle structure, Phys. Earth Planet. In., 114, 71-80, doi:10.1016/S00319201(99)00047-3, 1999. 